Est Ag 49 (2014) 275-341

\title{
Cristianismo versus cultos mistéricos: una lectura contextualizada del Bautismo en Rom 6
}

\author{
Ese bautismo de voluntad por la que esta se incorpora a la ética \\ Kierkegaard, $\mathbf{S}$.
}

Alfonso Vives Cuesta

RESUMEN: Se propone una revisión de las relaciones de las prácticas rituales por inmersión de agua entre el cristianismo y las religiones mistéricas contemporáneas. Para tal fin, se sintetiza el contexto en que estas prácticas se producen en el ambiente (Sitz im Leben) grecorromano helenístico, sin olvidar la influencia mucho más directa de las prácticas bautismales de los seguidores de Juan el bautista. A continuación, se introduce un sucinto Estado de la Cuestión de la historia de la interpretación de este fenómeno religioso, para calibrar qué argumentos se han esgrimido desde la escuela de historia de las religiones y de la propia exégesis y teología cristianas para explicar este fenómeno. Estudiando el caso del bautismo en Pablo y, concretamente, en el complejo pasaje de Rom 6, se trata de indagar hasta qué punto las prácticas bautismales del cristianismo de los orígenes son comparables a los misterios iniciáticos que implicaban un rito de características similares como una "muerte en Cristo que inaugura una nueva vida", puesto que estas ideas están bien desarrolladas en ese y otros pasajes del corpus paulino. Con argumentos procedentes de la sociología de la religión y de la antropología sociocultural, se entiende que el fenómeno se puede explicar como un caso de transferencia ritual entre religiones mistéricas y prácticas bautismales cristianas que permite explicar el complicado pasaje de Rom 6, si bien este tipo de influjo intercultural no excluye la relación genética con el trasfondo de las prácticas bautismales que habían sido desarrolladas especialmente por los judíos de los círculos de Juan bautista.

PAlabras ClaVe: Bautismo, Rom 6, cultos mistéricos, sacramentos. 
KEY WORDS: Baptism, Rom 6, mysteric cults, sacraments.

\section{Purificación con agua en el mundo greco-romano}

El uso del agua como medio de purificación es un elemento ritual típico en las religiones del mundo que se inscribe en el marco del fenómeno de las mediaciones.

También esta fue una práctica religiosa comúnmente desarrollada por griegos y romanos en el período correspondiente al surgimiento y posterior expansión del cristianismo. Desde tiempo casi inmemorial los lugares sagrados disponían de fuentes u otro tipo de depósitos de los que se extraía el agua para las ceremonias purificatorias de los fieles y oficiantes del santuario ${ }^{1}$.

\subsection{Uso general del agua como elemento purificatorio}

Una de las referencias más antiguas de ejemplos de inmersión con fines purificatorios aparece en Heródoto. En un pasaje de la descripción de su obra etnográfica explica que los egipcios consideraban a los cerdos como animales estigmatizados.

"Si un egipcio tenía contacto con un cerdo, se introducía en el río y se bañaba sumergiéndose con sus ropas" (Hdt 2.47.2).

El propio Heródoto en otro lugar atribuye a los egipcios la introducción de la práctica, posteriormente adoptada por los griegos, de no entrar a un recinto sagrado tras haber mantenido una relación sexual "sucia", ( $\propto \lambda$ ¿ Hdt. 2.64), es decir, sin que previamente haya habido un proceso purificatorio en el que intervenga el agua.

${ }^{1}$ Las referencias clásicas, surgidas en el ámbito de la Escuela de las religiones, para estudiar el influjo de las prácticas que presentaban un tipo de inmersión en el agua están bien representadas en los siguientes trabajos de conjunto: Leipoldt, J. (1928): Die Urchristliche Taufe im Lichte der Religionsgeschichte, pp.38-56. En la parte final de este artículo contamos con un anexo de los principales ritos de iniciación. Un tratamiento general muy bien orientado es el que presenta Nock, A.D. (1928): "Early Gentile Christianity and Its Hellenistic Background", en Rawlison, A.E.J. (ed.) Essays on the Trinity and the Incarnation, Longmans: London. 
Las prácticas catárticas realizadas con agua fueron muy frecuentes y extendidas en los ambientes helenísticos tanto paganos como judíos y lógicamente cristianos. En algunos casos, especialmente datados en época imperial temprana, se encuentran prescripciones y reglas para restablecer el estado de pureza de los aspirantes a iniciados en algún culto religioso. En este contexto se halla en el templo de Atenea en Pérgamo (133 d.C.) una inscripción que indica que "quienquiera que desee visitar el templo de la diosa, debe completar las lustraciones requeridas". Los medios de contacto con el agua podrían variar y la aspersión del agua a menudo formaba parte de los requisitos de otro tipo de rituales. Así en Lindos (ca. siglo II d.C.) se halla otro epígrafe con el siguiente texto: "serás purificado con agua lustral

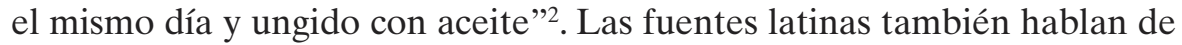
estas prácticas purificatorias previas. Después de la batalla, Virgilio hace recitar a Eneas el siguiente hexámetro.

me bello e tanto digressum et caede / attrectare nefas, donec me flumine abluero "no me está permitido de tamaña guerra y destrucción avanzar apartado, hasta que me lave en el río" (Virg. Aen. 277 y ss.).

Las purificaciones de los ritos iniciáticos por inmersión en el agua no sólo tuvieron lugar en los templos asociados a los cultos cívicos ordinarios, sino también en los santuarios curativos (incubationes dirigidas a Asclepio). Asimismo, también se recibían aspersiones purificatorias antes de prácticas extáticas (visiones), en celebraciones de tipo mágico y, fundamentalmente para el objetivo de este trabajo, en el ámbito de los cultos mistéricos.

La existencia de una fuente de agua para realizar las purificaciones fue un requisito en la fundación de los santuarios sanatorios. Los antiguos testimonios alusivos a la fundación de un santuario de Asclepio mencionan el baño del paciente y la ofrenda de un sacrificio inmediatamente antes de realizar la incubación ${ }^{3}$. Un baño purificatorio, de hecho, era una de las prácticas más habituales normalmente requeridas para los santuarios curativos. Elio Aristides menciona que durante su tratamiento en el santuario de Asclepio en Pérgamo se vio obligado a darse un baño ritual. Las excavaciones arqueológicas han confirmado la existencia de varias fuentes. También las purificaciones tenían lugar en los recintos oraculares. De fama inextinguible es la fuente de Castalia en Delfos, donde los sacerdotes del templo dél-

\footnotetext{
${ }^{2}$ Cf. Dittenberger, W. (1920): Sylloge Inscriptionum Graecarum, Leipzig, vol. 3, 582.

${ }^{3}$ Multitud de testimonios recogidos en Edelstein, E. J. y Edelstein, L. (1945): Asclepius: A Collection and Interpretation of the Testimonies, John Hopkins: Baltimore.
} 


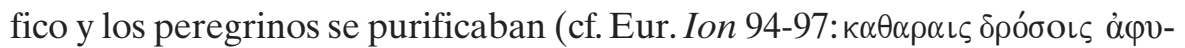
$\delta \rho \alpha v \alpha ́ \mu \varepsilon v o$ 'habiéndose bañado en aguas puras').

Entre las inscripciones de época imperial (ss. I-III d.C.) en el templo que honra al dios cuyo nombre helenizado era Mandulis en Nubia se encuentra un himno redactado por el decurión Máximo. En él se describe un sueño en el que se estaba bañando en las aguas del Nilo cuando Mandulis le impulsó a escribir el himno. Existe otra inscripción de autor desconocido que identifica a Mandulis con el sol. Esta visión de la mitología solar egipcia en clara alusión a la creencia de que el sol se introducía en el océano bañándose en él y emergiendo hasta dar lugar a una realidad con el día cada mañana fue apropiada por el cristianismo (cf. el mito de Faetón y la leyenda etiológica del surgimiento de la cordillera pirenaica), en la obra del famoso apologista cristiano del siglo II Melitón de Sardes. En su tratado sobre el

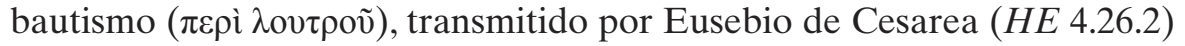
y de la que únicamente se conserva un fragmento de dudosa atribución. Una inmersión es parte de una ceremonia mágica descrita en el gran papiro mágico de París (PGM IV 43-45): "entonces dio un salto y cayó en el interior del río. Sumergiéndote tú mismo ( $\beta \alpha \pi \tau \imath \sigma \alpha ́ \mu \varepsilon v o \varsigma)$ en las ropas que tu llevas encima, camina hacia atrás por el agua, y tras cambiarse y ponerse vestidos frescos, debes partir sin mirar atrás". El papiro identifica la ceremonia con una "iniciación" ( $\tau \varepsilon \lambda \varepsilon \tau \eta \dot{)}$, pero Nock nota que la palabra se utiliza en el marco de un uso ceremonial mágico, que se efectúa para la realización adecuada de un encantamiento, y concluye que la inmersión supone un rito previo para obtener el requerimiento mágico. La descripción que realiza Plutarco de las prácticas supersticiosas habla de "una mujer mayor que lleva a cabo purificaciones supersticiosas como sumergirse

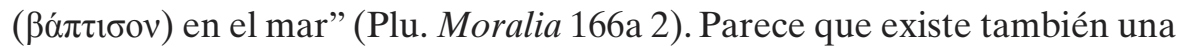
vinculación especialmente estrecha entre los textos de carácter supersticioso y las purificaciones por inmersión. En esta misma línea, el discípulo de Aristóteles, Teofrasto (Char. 16.2.13) comienza su caracterización de una persona supersticiosa afirmando que se trata de un individuo que no sale de casa sin lavarse las manos (ảmovi $\alpha \dot{\alpha} \mu \varepsilon v o \varsigma)$ y sin purificarse $(\pi \varepsilon \rho 1 \rho \rho \alpha v \alpha \dot{\mu \varepsilon v} \varsigma \varsigma)$ )". Es indudable que hay un componente moral ligado a este tipo de purificaciones, no es extraño, sin embargo, existen tendencias que apuntan en otra dirección. En este mismo sentido, Pitágoras en sus enseñanzas afirma: "la pureza se obtiene a través de limpiezas ( $\alpha \theta \alpha \rho \mu \tilde{\omega} v)$,

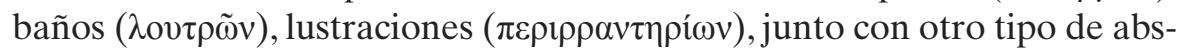
tinencias" . No fueron únicamente los filósofos los que pusieron una nota

\footnotetext{
${ }^{4}$ Cf. referencias tomadas por Diógenes Laercio, Vit. Phil. 8.33.
} 
moral sobre las purificaciones rituales. El poeta latino Ovidio aborda el tema afirmando: "nuestros antepasados creyeron que todos los pecados y causas de maldad podrían ser eliminados de una sacudida por medio de una purga". Asimismo, en los Fastos (2.35-38) el poeta de Sulmona señala que Grecia ha dado el ejemplo de que el culpable de un delito puede librarse de sus crímenes por medio de lustrationes. Unos versos más adelante (Fasti 2.45 y ss.) ironiza al indicar que "sólo los tontos creen que la mancha de un horrible crimen puede quedar limpia por el agua del río".

El tono de airada crítica que trasluce a estos textos demuestra que las lustrationes eran vistas como elementos que trascendían sus funciones ceremoniales previas. Los judíos como Filón de Alejandría no cabe duda de que tuvieron acceso a este tipo de ceremonias dentro del paganismo. Estos autores se hacen eco del mismo tono crítico que está presente en estas composiciones, como se hace notar en la siguiente nota que hace clara alusión a los poetas judíos. Veamos dos ejemplos a este respecto:

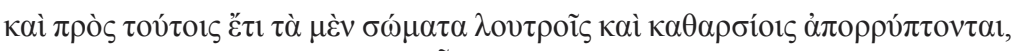

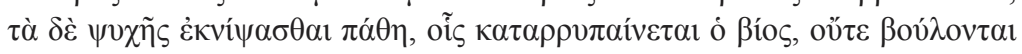

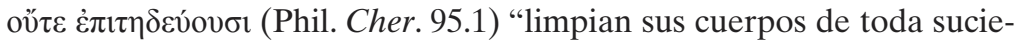
dad con baños y purificaciones, pero ni desean ni intentan diluir de su alma las pasiones por las que la vida está contaminada".

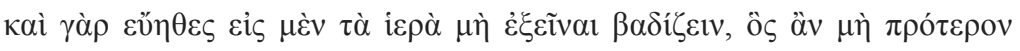

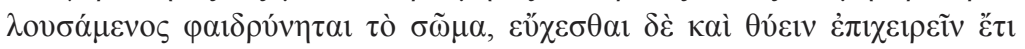

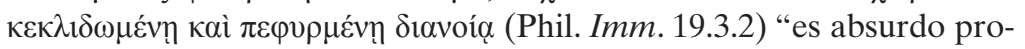
hibir la entrada a los templos a una persona que previamente no se ha lavado ni ha limpiado su cuerpo, y ponerse a rezar y a tratar de hacer sacrificios con la mente sucia y contaminada”.
\end{abstract}

\title{
1.2 Las inmersiones en agua en las religiones mistéricas
}

Un interés especialmente particular para nuestra reflexión lo representan los baños con agua presentes en muchas prácticas ligadas a cultos mistéricos. Ya hemos dicho que muchos autores de la escuela de las religiones las han asociado con el bautismo cristiano (cf. capítulo 2). Los misterios expresaron originalmente ideas de pecado, renacimiento, muerte mística, vida interna e iluminación, pero estas ideas estuvieron asociadas primeramente con la ceremonia como un todo y no primariamente con la purificación por medio del agua específicamente ( $c f$. Nock 1952; Burkert 1996). El uso del agua en estos ritos cumplía exclusivamente una función preparatoria, podría decirse que pre-iniciática, en la misma línea de actua- 
ción que el resto de los ritos mencionados anteriormente. Los investigadores que han situado en paralelo el uso del agua en los ritos mistéricos con el bautismo cristiano han mezclado los baños rituales preliminares con los efectos mismos de la iniciación, han malinterpretado los textos, o los han leído parcialmente atribuyéndolos a fuentes cristianas secundarias tardías que, en su opinión, pasaron un filtro cristianizador, dando un nuevo significado a sus ceremonias. De entrada ya se observa, con todo, una diferencia notable atribuida a la relevancia del agua (v̋ $\delta \omega \rho)$ en los misterios y en su uso para el cristianismo. Los baños rituales constituyeron una iniciación preliminar para la iniciación: en el cristianismo fueron fundantes y básicos para el centro de iniciación a la Iglesia ${ }^{5}$.

Comenzaré señalando algunas notas sobre el orfismo. $\mathrm{Si}$, como indican los amplios y sugestivos estudios de la escuela española de Bernabé (2006), el orfismo fue propiamente hablando una "religión mistérica" sigue siendo una cuestión abierta, pero yo lo hago notar aquí porque representa algunas ideas asociadas a los misterios. Los órficos se caracterizaron por realizar actos purificatorios, que se apartaban de sus prácticas obligatorias ceremoniales. Por ejemplo, hay un poema épico que, en clara intertextualidad con el género argonáutico de Apolonio de Rodas, presenta numerosos elementos propiamente órficos ${ }^{6}$. En esta obra se atribuye a Orfeo una regla ritual que ha de cumplirse: "no puedes regresar a tu casa sin que hayáis limpiado antes ( $\dot{\varepsilon} \kappa v i ́ \varphi \eta \sigma \theta \varepsilon$ ) tu mancha en las sagradas purificaciones

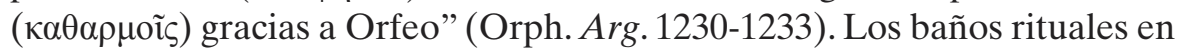
los misterios no fueron ritos secretos, sino que fueron bien conocidos y tuvieron un carácter público.

Respecto a los misterios de Eleusis se constata la existencia de tres niveles de iniciación. Los "pequeños misterios" fueron ritualizados durante los meses de Febrero / Marzo en las orillas del río Iliso, fuera de las murallas de Atenas. Como parte integrada en este ritual se incluía un baño por inmersión completa en el Iliso. Por otro lado, las ceremonias que tenían que ver con los grandes misterios celebradas en septiembre también tenían una duración de diez días ${ }^{7}$. Al tercer día los candidatos se dirigían al mar situado entre Atenas y Eleusis para ser bañados. Cada uno de los mistas, tomaba un cerdo con el que se bañaban (cf. la noticia sobre un baño iniciático en el puerto del Pireo procede de Plutarco (cf. Phocion 28.3). A continuación, se

\footnotetext{
${ }^{5}$ Cf. "Hellenistic Mysteries and Christian Sacraments", Mnemosyne 52, ser. 4-5, 97-104.

${ }^{6}$ Una revisión completa, amplia y erudita sobre el papel del orfismo lo constituye la obra de conjunto de Bernabé, A. y Casadesús, F. (eds.) (2008): Orfeo y la tradición órfica, Akal: Madrid.

${ }^{7}$ Cf. Ferguson, E. (2003): Backgrounds of Early Christianity, especialmente pp. 256-259.
} 
procedía a sacrificar el cerdo en honor de la diosa Démeter. Tanto el baño como el sacrificio pueden entenderse como purificaciones. La noche del séptimo día enmarcaba la experiencia de purificación propiamente dicha. El grado más alto de iniciación, las llamadas Epopteia, podría recibirse un año

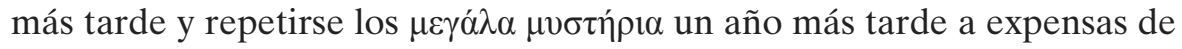
una Revelación de mayor entidad por parte de los iniciados. De hecho, la arqueología nos ha rescatado una fuente en las proximidades de la entrada al santuario que puede haber servido para abluciones por parte de los visitantes. Junto a los Grandes Propileos, la gran entrada al santuario, es la fuente Calícoros, donde las mujeres de Eleusis bailaban y elevaban sus oraciones a la diosa. El museo de Eleusis conserva un largo relieve del siglo IV a.C. en el que se representa a Perséfone (Kore, la hija de Démeter) purificando a un joven iniciado que aparece desnudo. Perséfone destaca siendo dos veces de la altura del niño de acuerdo con la norma de la perspectiva jerárquica que regía en las convenciones escultóricas de la época clásica. La deidad utiliza una concha para verter agua sobre la cabeza del iniciado de modo que se puede reconstruir claramente la escena de purificación de un joven antes de ser iniciado (vid. cap. 3.3 sobre el "bautismo" en Eleusis). El estudio de este relieve se ha pensado que puede ser pertinente para el estudio del trasfondo ritual del bautismo cristiano, puesto que en el arte cristiano el bautizando aparece, de un modo similar, desnudo y representado a una escala mucho menor que el bautizador ${ }^{8}$. Sin embargo, en el arte paleocristiano, la mano del bautizador descansa sobre la cabeza del que recibe el bautismo.

La iniciación en los misterios de Dioniso también incluía un rito iniciático que suponía un baño lustral. La madre de Publio Aebucio, según el testimonio del historiador Tito Livio (Hist. 39.9.4), nos relata las diversas etapas que conducían a la iniciación mistérica (continencia durante diez días y baños rituales purificatorios [pure lautum]). Pausanias (Desc. 9.20.4) nos transmite una información muy valiosa sobre las mujeres de Tanagra que, según su testimonio, antes de las orgías de Dioniso bajaban al mar para realizar purificaciones ( $\kappa \alpha \theta \alpha \rho \sigma i ́ \omega v)$ y eran atraídas por Tritón mientras iban

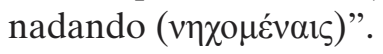

En Roma, el poeta satírico Juvenal ironiza sarcásticamente con las propias supersticiosas de las mujeres, cita como ejemplo un devoto de la Madre de los Dioses, en el caso de Cibeles:

\footnotetext{
${ }^{8}$ Encontramos algunas referencias a los primeros bautismos cristianos en Leclercq, $\mathrm{H}$. (1925): "Baptême de Jésus", en Dictionnaire d'archéologie chrétienne et de liturgie, vol. 2, cols. 346-380, Letouzéy et Ané: Paris. Información más detallada la podemos observar en Mielke, U. “Taufe, Taufszenen”, en Lexikon der Christlichen Ikonographie vol. 4, Herder: pp. 244-247
} 
hibernum fracta glacie descendet in amnem, ter matutino Tiberi mergetur et ipsis uerticibus timidum caput abluet, inde superbi totum regis agrum nuda ac tremibunda cruentis erepet genibus (Juv. Sat. 6.522.525) "en invierno, debe bajar hasta el río por la mañana, romper el hielo, y hundirse hasta en tres ocasiones en el río: hunde su cabeza temblorosa incluso en las aguas arremolinadas, de las que sale gateando desnudo y con tiritona".

Juvenal no explica si esta práctica fue hecha como un acto de ascetismo, para ganar el favor de la diosa, o en respuesta a su mandato para complacerla. Seguramente, se tratase de un rito anual. Es notable esta explicación como trasfondo de la práctica bautismal cristiana tanto en lo que se refiere a la desnudez como a la triple inmersión. La explicación más circunstancial de una iniciación que nos ha llegado a nosotros concierne a la iniciación de Lucio al culto de Isis en Corinto. La descripción procede de las Metamoforsis de Apuleyo, "novela" del tercer cuarto del siglo II d.C, concretamente en el libro IX ${ }^{9}$. Los elementos preliminares del ritual son claros.

\begin{abstract}
"En el momento que el sacerdote considera más oportuno, rodeado por un grupo de devotos, yo me dirijo a los Baños (balneas). Allí, después de limpiarme con el baño habitual (sueto lavacro), Mitras, el gran sacerdote del culto de Isis en Corinto, invocó el perdón de los dioses, y rociando de agua mi cuerpo (circumrorans), me limpió (abluit) con toda pureza”.
\end{abstract}

A estos actos les siguieron diez días de ayuno. Entonces, sin revelar los secretos del rito, Apuleyo detalla las visiones que el iniciado puede contemplar e incide en que es un espectáculo vedado a nuestros ojos. En los pasajes inmediatamente posteriores se narra la iniciación propiamente dicha. $\mathrm{Al}$ amanecer Apuleyo se vestía con una túnica de lino, tomaba una antorcha y se presentaba ante la visión del gentío. Una comida ritual celebrada tres días después concluía las ceremonias iniciáticas. Más tarde, en Roma, Apuleyo recibió la iniciación en los misterios egipcios de Osiris y accedió al rango de sacerdote. El propio Apuleyo (11.16 y 21) habla de sí mismo como un "renacido" (renatus) y define el rito de iniciación en su conjunto como realizado con el fin de imitar una muerte voluntaria y la obtención de una vida obtenida por la gracia” (11.21).

\footnotetext{
${ }^{9}$ Cf. J. Gwyn Griffiths (1975): Apuleius of Madauros, The Isis.-Book (Metamorphoses, Book IX): Introduction, Translation and Commentary, Études préliminaires aux religions orientales dans l'empire romaine 39, Leiden:Brill.
} 
Las prácticas purificatorias de Apuleyo incluían tanto un baño como una aspersión. Otras fuentes mencionan diversas inmersiones y aspersiones en la apertura diaria de los templos. Los templos de Isis que han sido excavados en Delos y en Pompeya muestran criptas conectadas con estos sistemas de aguas.

Como tendremos ocasión de analizar más detalladamente (vid. infra) el autor latino tardío Tertuliano de Cartago (ca. 200 d.C.) se refirió al uso del agua en las religiones de Isis y Mitra: "en ciertos ritos sagrados, los gentiles son iniciados en los misterios por medio de un baño [lavacrum] para pertenecer tanto a Isis, como quizá a Mitra". Tertuliano utiliza indistintamente el término "iniciado" en un amplio sentido que cubre el complejo total de las ceremonias asociadas a la iniciación (asumiendo que él conociese mucho sobre ellos). Otra posibilidad es que el uso de esta terminología por el padre apologista se deba a un deliberado interés por contrastar y establecer tensión entre los ritos mistéricos y los cristianos. En De Baptismo 5 (vid. infra para una descripción más detallada del pasaje), se describen los efectos purificatorios que por norma general se adscribían al agua. De hecho, Tertuliano desciende a los detalles y llega a establecer de qué modo pueden resultar efectivos los ritos en los que interviene el agua al servicio del Dios vivo. Por otra parte, afirma que estos usos paganos no son otra cosa que imitaciones demoníacas de la acción de Dios en el bautismo. De hecho, deliberadamente exagera por oposición los paralelismos, afirmando que "el demonio practica el bautismo sobre los suyos"

Tertuliano es una de las pocas fuentes literarias sobre la iniciación en los misterios de Mitra para la que la mayor parte de nuestro conocimiento procede, por otra parte, del estrato arqueológico real. Entre estos elementos, aparece un extraordinario mosaico de mármol procedente del Mitreo de Felicísimo en Ostia, donde se describen los siete grados de iniciación propios del iniciado en el mitraísmo ( $c a$. III d.C.). La sección para cada grado, puras alegorías, muestra un gran vaso, quizá una alusión a una purificación preliminar por agua antes de entrar en la serie de las iniciaciones. Los frescos en el Mitreo de Santa Prisca en Roma representa cada grado de iniciación, dentro de la escalinata de siete grados, que invitan al nuevo adepto a alcanzar un grado cósmico, recibiendo sucesivamente la protección de los diversos dioses planetarios ${ }^{11}$.

\footnotetext{
${ }^{10}$ Cf. una detallada discusión sobre este pasaje se encuentra en Nock, A.D. (1927): "Pagan Baptism in Tertullian”, Journal of Theological Studies 28, pp. 289-290.

${ }^{11}$ Cf. Clauss, M. (2000): The Roman Cult of Mithras: the God and His Mysteries, Edinburgh:Edinburgh University Press.
} 
En el mismo orden de cosas respecto al bautismo cristiano, debe situarse la purificación ritual que recurre a la utilización de sangre, en lugar de agua. Esta práctica se denomina taurobolium y se encuentra en el culto de Cibeles y Atis. Una persona se introduce en un agujero en el fondo de la tierra sobre el que se coloca un trozo de madera. Se coloca un toro encima de la estructura de madera y se procede a darle muerte con una espada. Una vez dispuesto esto, se deja que la sangre pase por los orificios de la caja de madera y la persona que se coloca ante ella se embadurna con la sangre o incluso puede comenzar a beberla. Este es el relato del ritual que podemos reconstruir a partir de la información que nos lega Prudencio ${ }^{12}$. Aparte de esta fuente literaria, la mayor parte de los datos sobre el taurobolium proceden de inscripciones de los siglos II al IV de nuestra era. El taurobolium experimentó una evolución a partir de sus formas originales.

Solamente en la última parte del siglo IV tenemos constancia de que el rito fue hecho para el beneficio de otros o de uno mismo. Las inscripciones anteriores reflejan sin lugar a dudas un acto de consagración o dedicación. Unas pocas inscripciones hablan de la persona como "renacida", normalmente por un período de veinte años. Concretamente, una inscripción datada en el año 376 d.C. ha recibido mucha atención porque habla de la persona como "renacida para la eternidad" (in aeternum renatus) ${ }^{13}$. El taurobolium compartía con las iniciaciones mistéricas "más canónicas" la promesa en la recepción de los favores divinos. Podrían ser para uno mismo o bienestar destinadas para los demás.

Incluso en ocasiones podrían ser una preparación para la vida en el más allá. Por otro lado, también fue una forma de sacrificio, que podría ser público y no secreto, y podría ser repetido. En conclusión, cabe decir, que pese a ser una opinión ampliamente defendida por la crítica moderna, el taurobolium no fue ni un tipo de rito iniciático, ni tampoco una parte integrante en los misterios de Cibeles, por lo que su concurso en este estudio de tipo comparativo debe situarse en un segundo plano.

La pregunta que se impone a estas alturas y que nos puede servir para cerrar el capítulo es la siguiente: ¿fueron los baños, abluciones o inmersiones con agua fija de cualquier tipo de ritual mistérico? En este sentido es interesante mencionar al poeta cómico Éupolis quien escribió una pieza

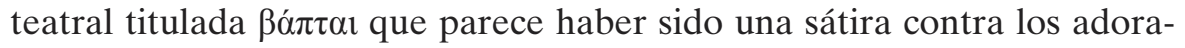
dores de la diosa tracia Cotito. Apoyándose en argumentos de tipo material,

${ }^{12}$ Cf. Prud. Carm. X, 1006-1050, en un relato sobre las coronas de los mártires. Cf. Duthoy, R. (1969): The Taurobolium, its Evolution and Terminology, Leiden:Brill.

${ }^{13}$ Cf. CIL 6.510. 
J. Hubaux sostiene la hipótesis de que la basílica subterránea próxima a la Porta Maggiore en Roma fue dedicada a esta divinidad, próxima iconográficamente a Cibeles, y sirvió como punto de encuentro de sus fieles, los Baptae, en Roma ${ }^{14}$. Hubaux interpreta el bajorrelieve sobre el muro en el ábside de la basílica que representa una inmersión y propone que el rito de iniciación consiste precisamente en el contacto con el agua. No obstante, aunque el contenido de estas imágenes permanece bajo la apariencia de un misterio, puesto que, si bien las escenas sobre el muro y las funciones de la basílica están abiertas a muchas interpretaciones, todavía no existe un consenso general.

Por último, en este repaso de las principales prácticas mistéricas relacionadas con el agua hemos de mencionar la existencia de un santuario de Cábiros en Tebas que contiene dos vasijas dispuestas en torno a una canalización que desemboca en un túnel. Las vasijas y el túnel parece que forman parte de un recinto destinado a baños rituales y ceremonias, pero la naturaleza de estos elementos nos es desconocida ${ }^{15}$. Finalmente, una inscripción sobre los Coribantes se refiere a un baño que realizan los que han sido iniciados, pero no está claro si el baño fue anterior a la iniciación o parte de la propia iniciación.

Eduard Stommel en un artículo muy influyente ha proporcionado el modelo de argumentación más idónea de los baños rituales del mundo grecorromano con el fin de situar estas prácticas en el punto de referencia de la administración del bautismo cristiano ${ }^{16}$. En él insiste en el carácter ritual de este tipo de baños señalando los paralelismos con las primeras prácticas bautismales cristianas y situándolos en plano de igualdad las prácticas de unción de todo el cuerpo con aceite y las prácticas bautismales del NT. En general, también las prácticas purificatorias del AT se realizaban por aspersión, por lo que no sería de extrañar que hubiera una continuidad manifiesta entre ambas realidades. La mayor contención a los paralelismos defendida por Stommel tiene que ver con el hecho de que en la antigüedad el fiel que iba a recibir el baño se mantenía desnudo mientras se le rociaba el agua sobre el cuerpo. No obstante, como hemos visto, los datos son demasiado escasos y fragmentarios como para realizar generalizaciones. Platón, utilizando una imagen basada en estas prácticas mistéricas, señala:

\footnotetext{
${ }^{14}$ Hubaux, J. (1923): “Le plongeon rituel”, Musée Belge 27, pp. 5-81.

15 Bruns, G. (1967): "Kabirenheiligtum bei Theben: Vorläufiger Bericht über die Grabungskampagnen 1964-1966”, en Archäeologischer Anzeiger, 1967, Berlin : De Gruyter, pp. 228-273.

${ }^{16}$ Stommel, E. (1959): “Christliche Taufriten und antike Badesitten”, Jahrbuch für Antike und Christentum 2, pp. 5-14.
} 


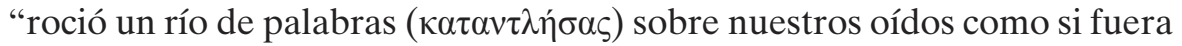
un baño asistido". Las representaciones iconográficas más antiguas de aplicación externa del agua al iniciado ofrecen una amplia variedad de métodos. La cerámica vascular policromada de la Grecia clásica nos ofrece varias escenas en las que el agua interviene como un principio fundamental: una figura agachada, mujeres bajo la espuma del agua que sale de las fuentes que están sobre sus hombros, atletas rociándose agua y hombres reunidos en torno a una jofaina extrayendo paladas de agua abundan como escenas pictóricas típicas en este tipo de $\operatorname{artes}^{17}$.

Hasta ahora hemos pasado revista a las fuentes arqueológicas y literarias que de manera directa nos aportan una visión general sobre los ritos que implican una inmersión acuática en el ambiente helenístico griego e imperial romano (Alto Imperio). Pasando al ámbito estrictamente mítico, en ese mismo contexto cultural merece la pena señalar que encontramos una versión de un mito tardío del ciclo troyano en el que interviene la diosa Tetis y su hijo mortal Aquiles. En ese relato se habla de una inmersión que se realiza con un propósito especial. Para conseguir hacer su hijo invulnerable ante las refriegas de las luchas, Tetis lo hace sumergirse en la laguna Estigia, río mitológico que atraviesa de extremo a extremo el inframundo. La versión más antigua de este célebre texto procede del poeta latino Estacio, del final del I siglo d.C. Estacio dramatiza la escena otorgándole a Tetis la palabra, como queda reflejado en el siguiente pasaje que reproducimos del original latino:
namque modo infensos utero mihi contuor enses, nunc planctu livere manus, modo in ubera saevas ire feras; saepe ipsa-nefas!-sub inania natum Tartara et ad Stygios iterum fero mergere fontes (Stat. Achilleida 1.134) "[...] estoy llevando a sumergirse a mi hijo nuevamente a las aguas de la Estigia”.

El texto no deja lugar a dudas, si se circunscribe a un ámbito de aplicación estrictamente surgido en la religiosidad del paganismo helenístico. Es evidente que el pasaje ilustra la necesidad de la inmersión total para completar la salvación del individuo. Este valor del término mergere "sumergir hundir (sc. en un líquido)" es el que ha sido trasvasado al período de com-

${ }^{17}$ La monografía más completa sobre los baños en la Antigüedad Clásica que conocemos es: Yegül, F. (1992): Baths and Bathing in Classical Antiquity Cambridge: MIT Press, pp. 17-21. A él remitimos para realizar una valoración general sobre las fuentes del período romano que hablan de los establecimientos de baños públicos (termas, frigidarium, caldarium, etc.) que por razones de espacio ahora no vamos a completar. 
posición de los textos del NT, que utiliza el calco semántico correspondiente en griego basado en la raíz $\beta \alpha \pi \tau \tau^{18}$.

\section{Estado de la Cuestión: Cultos Mistéricos y Cristianismo}

\subsection{Fundamentación histórico-comparativa de los ritos de iniciación}

Una corriente muy extendida de investigadores defienden como doctrina recepta que no es posible hablar de que en el origen de la iniciación cristiana se deba contar con la posibilidad real de influencia alguna de los misterios greco-orientales. A la consolidación de estas opiniones debemos opiniones tan autorizadas en el campo de la antropología religiosa y de la historia de las religiones como las de BIANCHI, U. (20023: 196), a pesar de las cuales, parece que una opinión tan tajante no puede sostenerse: ${ }^{19}$

"[...] la presencia eventual de temas iniciáticos en el cristianismo primitivo no implica necesariamente influencia de las religiones de los misterios. (...) Más, aun, no es preciso ni siquiera suponer que el cristianismo haya tomado algún tema iniciático de otra religión [...] la iniciación acompaña siempre a toda nueva revalorización de la vida espiritual”.

Resulta necesario resaltar las implicaciones antropológicas en clave universalista de los ritos de iniciación. El denominador común de todas estas prácticas entre las que podemos incluir también los ritos bautismales cristianos, comporta una experiencia existencial y como tal apunta a una dimensión supra-cultural y supra-histórica (cf. Martín Velasco [2006: 99]). El motivo central a todos los ritos de iniciación supone una ruptura de nivel, cuya esencia consiste en el paso de la vida "natural" a una nueva vida pro-

\footnotetext{
${ }^{18}$ Para un estudio completo de la terminología bautismal en el NT y, en un marco más general, en el griego del período helenístico vid. Ferguson, E. (2009): "Words from the baptroot in Classical and Hellenistic Greeks", en Baptism in the Early Church: History, Theology and Liturgy in the First Five Centuries". Sigue siendo imprescindible la consulta del diccionario de Kittel, G. (ed.) (1968) s.v. $\beta \alpha ́ \pi \tau \omega ~(\beta \alpha \pi \tau i \zeta \omega)$.

${ }^{19}$ Cf. Eliade, M. $\left(2002^{5}\right)$ Iniciaciones Místicas, Taurus: Madrid, pp. 10 y ss. Existe mucha bibliografía al respecto en perspectiva general amplia. En este panorama general es importante señalar la obra en conjunto del historiador de las religiones Bianchi, U. (ed.) (1965): Transition Rites. Cosmic, social and individual order, L'Erma, E.J. Brill : Roma/Leiden. Es significativo que una revista teológica tan importante como Concilium también dedicara en 1978 un número monográfico, el 132, a la cuestión de los ritos de tránsito: "Liturgia y fases de la vida humana".
} 
curada por la aparición de lo sagrado y el contacto con ello. Muy certeramente resume Eliade la esencia de la iniciación en estos términos (op. cit. 13): "expresado filosóficamente, la iniciación corresponde a un cambio ontológico de las formas estructurales de la existencia". Esta transformación óntica integral que supone un renacer esplendoroso a un nivel superior de nuestra experiencia de ser, alumbrada tras la irrealización de nuestro proyecto de vida previa siempre lleva aparejado el marchamo de auto-trascendimiento, de nacer para el espíritu, alejándonos de la realidad inmediata. Es por esta razón, por la que Eliade justifica, como trataremos de defender en nuestro trabajo presente, los más que plausibles contactos históricos entre el cristianismo y la religión de los misterios en los que es central el tema de la muerte renovadora de la vida.

Pues bien, tanto en el estudio de los sacramentos en general, como en el del bautismo en particular la relación entre la praxis de las religiones mistéricas y del cristianismo se han consagrado como una vexata quaestio de la que se pueden extraer conclusiones metodológicas muy variadas e incluso contradictorias, ya no sólo, sobre las relaciones intrínsecas entre misterios y cristianismo en el orden externo o ritual, sino, especialmente, y eso es lo que más nos interesa, en la consideración "sacramental" de ciertas prácticas litúrgico-rituales que hunden sus raíces en los orígenes del cristianismo primitivo, observadas bajo la óptica de la antropología religiosa y sociocultural. Para hacer frente a esta reflexión tomaremos como punto de partida las discusiones sobre este tema que han formulado, desde presupuestos teóricos diversos, algunos especialistas. Antes de referirnos directamente a la cuestión del bautismo y de las prácticas de iniciación que van vinculadas a su praxis ritual convencional, nos detendremos en la cuestión más de fondo de comparación entre los cultos mistéricos y el cristianismo entrando a diseccionar el carácter soteriológico de ambos tipos de prácticas. La síntesis que ahora inicio, por tanto, exige una breve discusión sobre algunos aspectos metodológicos centrados en obras de referencia que, desde distintos parti pris, configuran las líneas maestras de este challenge todavía no completamente agotado en sus múltiples derivaciones y puntos de vista que cubre la espinosa relación entre cultos mistéricos y cristianismo.

Los primeros siglos de nuestra era configuran un mercado de creencias religiosas muy variado para los creyentes que buscan una salvación definitiva para sus almas. Tanto el cristianismo como las religiones mistéricas ofrecen posibilidades en cierto modo comparables de responder a la crisis espiritual dominante en este ambiente transcultural dominado por el helenismo globalizador que había inaugurado tres siglos atrás la actividad conquistadora y expansiva de Alejandro Magno. En esta variedad de ofertas 
soteriológicas, cabe preguntarse si, en atención a los datos que nos ofrece el NT, especialmente en la propuesta proyectada por el corpus paulino, fue el cristianismo simplemente una ramificación más de la multiplicidad de tendencias religiosas que contemplaban que tras la cruz había una salvación del alma y, en definitiva, si el cristianismo gozó desde su primera configuración doctrinal y en sus primeros pasos como religión autónoma (entendida, en términos de sociología de la religión, como faith y no sólo como belief) de tal exclusividad e independencia como para ser considerada la vera religio, haciendo uso de la definitiva ruptura con las religiones no monoteístas del ambiente circundante ${ }^{20}$. A continuación, presentaremos los puntos de vista de algunos de los considerados mejores planteamientos sobre la cuestión. Estas son algunas de las obras más representativas en el ambiente académico sobre tan controvertida cuestión:

(a) Ferguson, Everett (1987): Backgrounds of Early Christianity.

(b) Burkert, Walter (2005): Cultos mistéricos [trad. del original alemán: Antike Mysterien Kulte]

(c) Rahner, Hugo (1944): "The Christian Mysteries and the Pagan Mysteries", Eranos Meeting.

(d) Smith, Jonathan Z. (1991): Drudgery Divine: On the Comparison of Early Christianities and the Religions of Late Antiquity.

(e) Wagner, Gunter (1963-1967): Pauline Baptism and Pagan Mysteries.

Todas estas obras parten de diferentes presupuestos teóricos y explican el fenómeno de la influencia de los misterios en el cristianismo desde diversos puntos de vista, en ocasiones, incluso enfrentados. Esa es una de las principales razones de su elección que van desde el profundo alegato apologético que domina en el ambiente académico de cierta época con Ferguson (1987) a las visiones con más anclaje en el terreno de la historia de las

\footnotetext{
${ }^{20}$ Habría que considerar aquí la información que ofrecen los historiadores de las religiones recogiendo una definición de religión suficientemente omnicomprensiva como la que ofrece Sundermeier et alii. (1999): Was ist Religion? Religionswissenschaft im theologischen Kontext. Esa evolución religiosa revolucionaria que determina la ruptura entre las religiones anteriores y las que profesan un credo monoteísta ha sido muy bien reflejada por Jan Assmann (2006) en su obra ya traducida al español como La distinción mosaica o el precio del monoteísmo [trad. del original alemán: Assmann, J. (2003): Die Mosaische Unterscheidung oder der Preis des Monotheismus]. Assmann demuestra que el concepto de la "distinción" y la creación de una religión distinta de las demás deriva en la creación de la diferencia entre religiones superiores e inferiores, primarias y secundarias y, en definitiva, de religiones "verdaderas" y "falsas".
} 
religiones o en el comparativismo puro y duro como las de Burkert (2005) ${ }^{21}$. A continuación pasamos rápido examen a las aportaciones que han ofrecido estos estudios en lo relativo al bautismo. Pero antes de realizar el repaso de la parte crítica parece conveniente detenerse a escrutar qué posición ocupan los ritos bautismales dentro de la estructuración ritual.

El bautismo (gr. $\beta \alpha \pi \tau i \zeta \zeta)$ se interpreta como un rito de iniciación o de entrada a una realidad religiosa novedosa. En una perspectiva antropológica amplia, los ritos son mediaciones socioculturales utilizadas por los humanos para inhabitar la dimensión sagrada del misterio en la realidad consuetudinaria ${ }^{22}$. A través y gracias a la ritualización de la realidad-ambiente, las comunidades humanas establecen lazos de solidaridad entre sí, consolidan las pautas de la identidad intracomunitaria y, en una palabra, sancionan las experiencias religiosas que unen indisolublemente a una comunidad religiosa. Se suelen distinguir entre ritos de iniciación (entrada), de exclusión (penitencia) o de pertenencia (comunión). También existen otros tipo de ritos que ritualizan las etapas básicas de la vida (nacimiento, emancipación postadolescente, etc). El bautismo cristiano, en cierto sentido, se situaría en un nivel mixto entre estos dos últimos. De todas formas, el bautismo debe ser analizado, dentro de esta perspectiva ritualista, como un rito de iniciación o de entrada, que se sobreentiende, da acceso a una nueva realidad, a una nueva religión o a una nueva dimensión de la fe del creyente. La propia terminología cristiana ha denominado a estos ritos desde sus orígenes con vocablos procedentes de los cultos mistéricos ( $\mu v \sigma \tau \hat{́} \rho ı v)$, incluso anteriormente a la acuñación del término sacramentum asimilado a partir de la éxegesis practicada por las fuentes de la religiosidad romana ${ }^{23}$. La mayor parte de los investigadores que afrontan esta perspectiva se aferran a una metodología de trabajo que pretende sacar floridas conclusiones de un terreno más bien yermo, en la medida en que la escasez de fuentes y la muy frecuentemente oscura presentación que hacen de ellas los rituales cristianos, en ocasiones, convierte en una tarea imposible observar las relaciones entre ambos elementos. No olvidemos que las fuentes para el estu-

\footnotetext{
${ }^{21}$ Un estado de la cuestión interesante que aglutina sintéticamente las diferentes tendencias que en el contraste entre misterios paganos y cristianismo queda recogido en Martínez Maza, C. y Alvar, J. (1997): "Transferencias entre los misterios y el cristianismo: problemas y tendencias", en Antig. Crist. XIV, pp.47-59. Una visión de conjunto, en perspectiva igualmente comparativa, la podemos encontrar en Klauck, H. J. (2006): The Religious Context of Christianity.

${ }^{22}$ Disponemos en español de la edición francesa de un clásica en la materia: Van Gennep, A. (1008 [1968]): Los ritos de paso, Alianza Editorial: Madrid.

${ }^{23}$ Riedweg, Ch. (2003): Mysterienkulte.
} 
dio del bautismo, por ejemplo, no indican cómo celebraban el rito las primeras comunidades cristianas. De los textos se puede extraer que el bautismo cristiano hunde sus raíces en prácticas bautismales judías, sobre las que se ha asentado una plataforma de innovaciones rituales, entre las que se incluyen, muchas revestidas de los influjos de los cultos mistéricos. La sociología de la religión nos enseña que paulatinamente desde los primeros dos siglos de nuestra era los diversos grupos religiosos cristianos determinados por influencias ambientales de sustrato y superestrato, regularán en perspectiva y praxis cristo-céntricas, la nueva realidad sacramental en proceso de formación.

En cuanto al bautismo, ya hemos indicado que se concebía como un rito de entrada a la comunidad cristiana, que lleva implícito previamente un proceso de conversión. En conexión directa con otros movimientos mesiánicos que utilizaban ritos de inmersión acuática, como sucede con los grupos baptistas asociados a la figura de Juan el Bautista, en el bautismo cristiano no se encuentra en principio una fórmula fija que acompañe a la

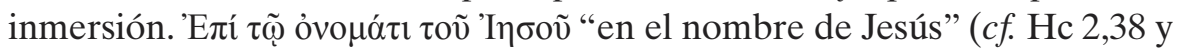
Rom 6,3-4) parece ser la más primitiva a partir de la cual se podrían haber desarrollado otras fórmulas trinitarias: "en el nombre del Padre del Hijo y del Espíritu Santo" que posteriormente se regularizarán como normativas. El bautismo es una marca de adhesión a la persona de Cristo, una verdadera profesión de fe, que se circunscribe en un ámbito celebrativo comunitario, por lo que también puede entenderse como una especie de iniciación en el movimiento de Cristo.

Ambas fórmulas rituales están presentes en uno de los textos más relevantes para la "institución" iniciática cristiana como es la Didajé. En este tratado de instrucción litúrgica de origen sirio datado a finales del siglo I d.C. se sancionan las diversas prescripciones rituales que hay que llevar a cabo en la praxis bautismal. Aunque no tenemos testimonios claros que nos permitan aclarar con rigor cómo celebraban los sacramentos las primeras comunidades cristianas, sabemos que el rito del bautismo en las primeras comunidades adquirió una importancia radical en la conformación de las comunidades, en la vida personal y en la vida comunitaria cristiana, revelando una fiel conjunción entre tradición de matriz judaica e innovación de influjos helenísticos, donde tienen una gran importancia los contextos locales, en los que se testimonian a menudo asentamientos de asociaciones religiosas directa o indirectamente relacionadas con las prácticas mistéricas ${ }^{24}$.

\footnotetext{
${ }^{24}$ Burkert, W. (2005): Los cultos mistéricos, Trotta, es la referencia más completa sobre estos elementos.
} 


\subsection{Misterios y cristianismo}

Sin pretensión de exhaustividad, trataré de dar cuenta en el presente capítulo de las primeras opiniones que desde dentro o fuera de los límites de la exégesis católica se ha entendido la relación entre Misterios y Cristianismo en términos generales y, en concreto, en lo que atañe a los ritos de iniciación cristiana.

\subsubsection{Everett Ferguson: Backgrounds of Early Christianity}

Ferguson adopta en su estudio sobre las interacciones entre cultos mistéricos y cristianismo una visión de claro carácter apologético, destacando la exclusividad de la práctica cristiana como "superior" en términos soteriológicos a los mistéricos.

Significativamente, basa esta lectura en un error metodológico de consecuencias decisivas en la interpretación de los vínculos entre cristianismo y cultos mistéricos en los tiempos de configuración del cristianismo. Su consideración parte de la idea de que los investigadores que han observado paralelismos entre cristianismo y misterios se basan en una inferencia errática de fondo que es una de las deficiencias que con mayor insistencia se han achacado al método comparativo en la historia de las religiones. La argumentación de los que se incardinan en la Escuela de las Religiones, opina Ferguson, comienza de forma inductiva con el fin de explicar ideas cristianas. Utilizan esas ideas para interpretar los datos cristianos, y, en los casos en que lo logran, se encuentran los misterios como fuente de las ideas cristianas (pp. 237 y ss.) como si la coincidencia entre dos elementos rituales dentro de un mismo contexto cultural fuese un argumento de suficiente peso como para justificar la existencia de paralelismos o, lo que es más importante, cierta dependencia genética entre ambas realidades culturales. Aunque, como se ha defendido por activa y por pasiva, el método comparativo no se debe explicar simplemente en términos de estricta verticalidad y dependencia diacrónica, sin embargo, esta argumentación que pone en relación misterios y cristianismo es claramente ambivalente en la medida en que los defensores académicos de la absoluta distintividad cristiana, a menudo han puesto mayor énfasis en definir los elementos que identifican el cristianismo resaltando que ellos presentan el mejor aspecto de distinción respecto a los misterios. A esta opción interpretativa se le puede achacar el 
hecho de que las diferencias dan por sentada la originalidad exclusivista del cristianismo $^{25}$.

Descendiendo a los datos y utilizando un comentario de cierta rotundidad del propio Ferguson en lo que se refiere a su consideración del bautismo:

There are no true parallels to baptism. Where water was applied it was done so for a preliminary purification, not as the initiation itself. The manner in which the initiation into the mysteries and baptism in the New Testament worked was entirely different; the benefit of the pagan ceremony vas effective by the doing (ex opere operato), whereas the benefit of baptism was a grace-gift of God given to faith in the recipient...all converts to Christianity received baptism, whereas initiation in the mysteries was for an inner circle of adherents.

El propio uso del lenguaje especializado de la iniciación que realiza Ferguson deja bien al descubierto cuál ha sido su punto de partida metodológico y qué objetivo tienen sus reflexiones. De entrada, obsérvese que Ferguson evita utilizar el término "iniciado" para referirse al receptor del bautismo cristiano, aunque no queda ninguna duda de que en ambos casos se ofrecen mecanismos de iniciación a un nuevo ámbito que implica una dimensión de la vida sacralizada del individuo que realiza la iniciación. Pablo deja clara esta distinción del proceso iniciático en Rom 6,1-10. Ferguson basa su crítica en la observación del hecho de que los cultos mistéricos no utilizaban el agua en sus ritos de iniciación, sin percatarse de que el elemento acuático estaba ya presente en otro tipo de ceremonias que utilizaban también el agua como mediación simbólica. Ferguson también utiliza un lenguaje ambiguo al establecer una distinción totalmente artificial en las experiencias místicas que le sobrevienen al iniciado en cada uno de los ritos. Si existe una iniciación ( $\tau \varepsilon \lambda \varepsilon \tau \varepsilon i ́ \alpha)$ como fundamento en la recepción o "po-

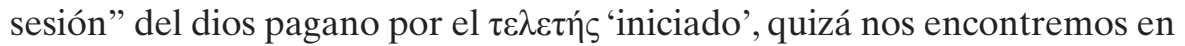
la misma perspectiva, salvadas las diferentes implicaciones dogmáticas, que en el esquema rahneriano de la recepción de la gracia cristiana en el Espíritu Santo del cristiano, que, en un doble sentido, procede de Dios y es Dios. La afirmación de que todos los convertidos al cristianismo han recibido el bautismo, mientras que la iniciación a los misterios ha quedado restringida a un círculo cerrado muy exiguo supone incurrir en un argumento tautológico. De la misma manera que todos los nuevos cristianos escogieron la conversión, y, por ello, recibieron el bautismo, así también todos aquellos que

\footnotetext{
${ }^{25}$ Cfr. Ferguson, E., Backgrounds of Early Christianity (1987).
} 
decidieron ser iniciados recibieron el beneficio de los misterios. La única diferencia ostensible entre ambas prácticas de iniciación puede explicarse a partir del alcance del concepto, por cierto, de gran funcionalidad y potencial explicativo de affordability que más tarde explicaremos con mayor precisión. En este punto, Ferguson adopta un punto de vista muy diferente al de la mayor parte de los investigadores. Así, en cuanto a la trasmisión de beneficios salvíficos al iniciado, comenta: "el beneficio de la ceremonia pagana resultó efectivo por actuar ex opere operato, mientras que la salvación obtenida por el beneficio del bautismo, fue una gracia de Dios, dado por la fe, en el receptor de la misma". Aquí se observa ya un primer punto débil en la argumentación de los que enfocan esta comparación desde la perspectiva de la apología exclusivista cristiana, creando distinciones artificiales y, en cierto sentido, falsas. Situar un intervencionismo exclusivo en el ámbito estrictamente sobrenatural impide un enfoque científico adecuado y sometido a las reglas de la demostración propias del método histórico-crítico. La idea de ex opere operato, es decir, de que la acción ritual directamente genera el efecto en el iniciado es interesante, pues supone afimar que como si estas virtualidades fuesen asumidas de manera mágica, automática por parte del iniciante. La propia divinidad o el proceso no intervienen en la cuestión. Como en los procesos mágicos, si conoces las palabras adecuadas ( $\tau \grave{\alpha} \lambda \varepsilon \gamma \delta$ ó $\mu \varepsilon v \alpha$ ), las propias acciones rituales ( $\tau \grave{\alpha} \delta \rho \alpha ́ \mu \varepsilon v \alpha)$ o los nombres

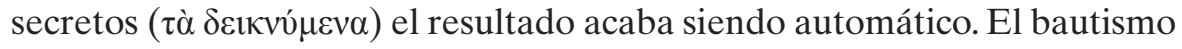
cristiano, por otro lado, no se presenta como un rito que supone admitir el resultado automáticamente, sino como un acto de fe del que Dios podría ofrecerse como donación graciosa. A primera vista, esta distinción es difícil de sustentar como básica. El rito, adecuadamente desarrollado, podría causar el beneficio. En el ámbito de la teología de los nombres, ya hemos visto que el cristianismo también invocaba la presencia de lo divino mediante la alusión directa a los nombres de Dios: Padre, Hijo y Espíritu Santo. Y cualquier fuerza que se desee invocar entre la performance del rito y la respuesta de la divinidad a la que va dirigida, resulta absurdo pensar hacer reverencias a uno, mientras gesticulamos ante el otro. El concepto pau-

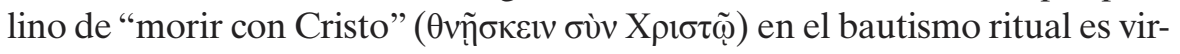
tualmente indistinguible en cualquier plano racional de lo que le sucedería al iniciado en los cultos mistéricos paganos cuando se iniciaba en los misterios de su propio Dios.

Desde la perspectiva contraria al paganismo, tenemos opiniones que contrastan en sumo grado con la visión apologética y cristianocéntrica de Ferguson. Burkert también reflexiona sobre el bautismo. En su opinión, "el bautismo propio" consiste en la inmersión en un río o bañera como sím- 
bolo del comienzo de una "nueva vida". Con todo, admite que hay algunos elementos en el primitivo bautismo cristiano que, sin distinción, nos traen al recuerdo las iniciaciones paganas.

El gran helenista Burkert reconoce que, probablemente, entre estos elementos se produjeron ciertos préstamos que acabaron penetrando en el cristianismo. Considera que varios de estos elementos fueron incluidos en la prácticas baptistas de Juan en el Jordán. No obstante, en esta dialéctica de influencias, parece obviarse un dato esencial: Juan ignora las diferencias evidentes que existen entre lo que se supone que ha sido el "bautismo de Juan" (producido en Hc 19,4 y comentado por Josefo) y la versión paulina, entendida como la recepción del Espíritu Santo. Este hecho, tal como se presenta en el pasaje de Hechos, le es desconocido a Juan. También cabe destacar otra ausencia en la argumentación de Burkert de un dato de importancia no menor. Pablo en toda su referencia al bautismo, no menciona ni una sola vez el propio bautismo de Jesús en el Jordán. Nunca se resalta la significación del bautismo, al presuponerse que presumiblemente estas tradiciones estuvieron circulando en la tradición cristiana incluso antes de que los Evangelios fueran escritos. Esto podría incluir el supuesto descenso del Espíritu Santo sobre Jesús, que pudo haber sido utilizado muy provechosamente por Pablo al conocer la imagen de que en el Bautismo el Espíritu Santo hacía su entrada en el iniciado. Por otro lado, también llama la atención el hecho de que Pablo no aporta ni un solo dato a propósito de la figura de Juan el Bautista. Finalmente, Burkert extiende el alcance de su esquema comparativo con prudencia al hacer notar que existe otro ritual, además del bautismo, radicalmente enraizado en la tradición judía: la unción con óleos que tampoco es contemplada en los misterios. Estos puntos de contacto no hacen otra cosa que reforzar la idea de que los ritos cristianos y las tradiciones previas conforman un sincretismo de elementos judíos y no judíos. La presencia de estos elementos foráneos no es menoscabo, contra la opinión de muchos investigadores a lo Ferguson, para la existencia de elementos propios. Esta precaución nos permite poner en la balanza los dos tipos de influencias y determinar cuánta es la cuota de deuda de las prácticas religiosas mistéricas griegas, especialmente, en lo que atañe a los aspectos centrales de la soteriología cristiana.

Muchos otros aspectos podrían extraerse de la exposición de Ferguson con el fin de observar en ella un subjetivismo cristianocéntrico de marcado tono exclusivista y finalidad apologética. Estos mismos postulados teóricos los hace extensivos Ferguson a la resurrección, al renacimiento de una divinidad, a las comidas compartidas (Eucaristía) y a la redención de los pecados. En todos estos elementos, Ferguson obvia los posibles paralelismos 
y centra su argumentación, en lo que entiende, como defensa de la causa cristiana, sin pararse a reflexionar que ciertas mediaciones religiosas pueden ser entendidas como universales mediante la experiencia de adhesión amorosa a un Dios personal y, por otro lado, negando las posibilidades históricas que en el polivalente y plural ambiente religioso de los primeros siglos eran, por otro lado, evidentes. Como conclusión a este apartado, simplemente sería oportuno recordar la comparación que realiza Ferguson entre las religiones salvíficas de corte helenístico y de fundamentación filosófica como el estoicismo frente al cristianismo. Ferguson llega a afirmar que el Dios-sabio personal del estoicismo no reporta ningún tipo de salvación ni inmortalidad en perspectiva moral. En palabras de Ferguson, el estoicismo no reporta la salvación ultramundana. Cuando uno muere, la parte divina regresa al Todo. Los estoicos no merecen ninguna clase de crédito, no generan ningún tipo de potencia salvífica, en la medida en que sólo las virtudes cristianas sustentan su base doctrinal en el axioma "Dios es amor". Las afirmaciones maniqueas son tanto más marcadas cuanto más entran en juego los criterios salvíficos del Dios cristiano para remarcar la buscada superioridad. Para el estoicismo, así como para toda la filosofía griega anterior al neoplatonismo, el objetivo de la humanidad es la auto-liberación "cobarde" de los miedos e inseguridades padecidos en esta vida. En otras palabras, una prometeica y deficitaria falta de üßpı en las relaciones hombre-Dios. Ni los cultos mistéricos, ni las religiones salvíficas conocieron jamás el amor redentor de un Dios misericordioso. De hecho, los estoicos llegan a extremar tan artificialmente su propuesta comparativa que introduce "el salvífico amor misericordioso de Dios" como elemento necesario ante la existencia de tantas personas malvadas que se impone necesariamente la intervención redentora de Dios. Con esta idea del carácter de redención que necesita el hombre, en lo hondo de su reflexión Ferguson culmina su tratado de apologética afirmando: "los misterios no ofrecieron un dios que fue enviado a la tierra para salvar a los hombres. Sus dioses (sc. los que intervienen en los Misterios) no se sacrificaron para salvar a la humanidad". Las deidades salvíficas de los cultos paganos no ofrecieron en sacrificio a sus dioses para conseguir el perdón sobre la humanidad. Pero si los dioses de los cultos mistéricos representaron fuerzas inherentes a la naturaleza, si sus acciones inherentes produjeron salvación, se sobreentiende que las fuerzas del amor y de la misericordia debían entrar en juego en la representación conceptual de la teología de estos movimientos religiosos mistéricos y teosóficos de la Antigüedad tardía.

Indudablemente esta interpretación se debe al contexto sincrético religioso del platonismo de la época. Durante el Alto Imperio romano el pla- 
tonismo fue una filosofía de minorías, con neta coloración religiosa (teosofía). El panorama filosófico de este período seguía estando dominado por un estoicismo ecléctico de corte posidoniano, con mezcla de elementos platónicos y aristotélicos. Los sectores más "laicos" de la sociedad, por su parte, se adherían preferentemente al aristotelismo. Celso cree poder dar razón de este fenómeno: "se adhieren al platonismo, porque desprecia a los demás como individuos de menos importancia; o al peripatismo, porque corresponde mejor a las necesidades humanas y admite con sensibilidad el valor de las cosas en la vida presente, aventajando en esto a los demás sistemas".

\subsubsection{Hugo RAHNER: Una evaluación teológica de los misterios ${ }^{26}$.}

H. Rahner fundamenta la superioridad de la doctrina cristiana sobre la experiencia religiosa de los misterios nuevamente en términos de exclusividad que está presente a lo largo de toda su obra. Uno de los mejores ejemplos de este tipo de aproximación se puede encontrar en su contribución a los Papers from the Eranos Yearbooks que ahora paso a comentar. Su opinión sobre la relación entre misterios y cristianismo se centra en una diferencia radical entre ellos. Rahner defiende que los misterios son una religión de sentimientos, que no apelan directamente al intelecto humano, que lo alejan de toda racionalidad y no conforman una doctrina o "dogma". Utilizando el ejemplo de los misterios de Atis, realiza una valoración externa y meramente ritualista de los misterios. Esta exterioridad hace que el

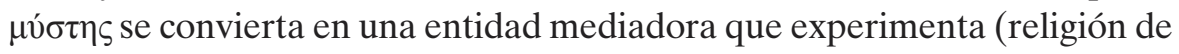
tipo patiens frente a otras de tipo dicens) que exonera al iniciado a emplearse en la interpretación racional, que para Rahner, es sinónimo de dogmática. En contraposición, nuestro autor defiende que la finalidad de la iniciación es aprender y no sufrir.

Toda esta apología de la superioridad cristiana que explota Rahner en su alegato sienta sus bases en la consideración de que las religiones que han surgido en el segundo tiempo "eje" de la tardoantigüedad occidental, tienen como principio rector su doctrina o su dogma. La pregunta, que clarifica evidentemente el terreno, se impone: si los cultos cristianos, al igual que los cultos mistéricos, tenían por objeto la salvación del individuo, cómo pue-

\footnotetext{
${ }^{26}$ Rahner, H. (1944): “The Christian Mystery and the Pagan Mysteries", Papers from the Eranos Yearbooks, pp. 337-401.
} 
den estos últimos lograrla, sin intelectualizar el significado que está detrás de estas experiencias religiosas.

Es difícil detectar en este punto a qué hace referencia Rahner cuando recurre a la dimensión intelectiva de la fe cuando todo apunta al rostro oculto de Dios, insondable y dependiente de la fe. Aquí uno tiene en cuenta los ecos de la doctrina paulina sobre el crucificado en la que aparece una referencia intelectual un tanto extraña a ojos del entendimiento humano. También se puede traer a colación la voz más tardía de Lutero cuando afirmaba que la Razón (ratio) es el mayor enemigo que tiene la fe: "la fe debe pisotear toda la razón, sentido y entendimiento". Rahner incluso llega a apelar a la autoridad de los logia al hablar del "misterio del Reino de los cielos" (Mt 13,11 basado en Mc 4,11), que debe estar, como Rahner señala, "como un manto que recubre y que permite ver y no ver, oir y no oir".

Estas opiniones parecen establecer una contraposición infranqueable entre paganismo y cristianismo. Sin embargo, los testimonios de los antiguos a propósito del tema de que la salvación se debe lograr contraviniendo la pura razón o que los mismos dioses ocultaban la verdadera razón, no se sostiene como un sentimiento defendido por los antiguos. Ciertamente, los cultos mistéricos pusieron poco énfasis en la idea del entendimiento de las obras de salvación, pero, al menos, no declararon abiertamente el abandono de su esperanza de hacerlo. De hecho, el carácter mitológicamente orientado de muchos ritos griegos puede haber promovido la "comprensión" de los mitos que implicaban a un dios salvador, por encima de la experiencia de los ritos. De hecho, hay datos que apuntan en este sentido. La exigencia de silencio en ciertas prácticas mistéricas, así como la prohibición de que los indignos profanaran este ámbito son aproximaciones a esta idea. A tal efecto, Rahner cita el corpus hermeticum: "exponer este tratado imbuido de toda la Majestad de Dios para el conocimiento de muchos podría consistir en presagiar la mente divina" o a los pitagóricos que se aproximaban a una mística específica al afirmar que "los bienes del conocimiento no deben ser comunicados a aquel cuya alma no esté purificada" (1944:364). El cristianismo, por su parte, contempló las verdades divinas como esencialmente inaccesibles de modo que sólo Dios pudo conferir y propiciar el conocimiento.

Por todo lo anterior se infiere que la religión cristiana nunca se presenta como una religión de la palabra desnuda, de la mera razón o de la ley ética, sino de la palabra al viento que potencialmente expande su mensaje, de la sabiduría amorosa, de la gracia oculta en los símbolos sacramentales, y de ahí, también en la religión del misticismo, en la que las infinitas profundidades ocultas de Dios son reveladas tras signos rituales y palabras concretas. Al contrario, este es un elemento cristiano decisivo, específico y genuino. 
Dios es únicamente el mistagogo de estos misterios. Cuando su espíritu confiere el poder de la visión se convierte en غ̇ंó $\pi \tau\rceil \varsigma$ del misterio cristiano. En torno a estas ideas, para lograr su objetivo de establecer los puntos de contacto entre misterios y cristianismo, Rahner sitúa el epicentro de la distinción en la separación entre natural vs. sobrenatural, entre misterios naturales y misterio oculto cristiano, entre ciclos de la naturaleza recurrentes y teleología salvífica cristiana. Surgido de un ambiente cultural básicamente naturalista, el cristianismo se emancipó de las mediaciones naturalistas. Las obras de este mundo, incluso el intelecto humano, se concibieron como irrelevantes e incluso negativas destinadas a la autodestrucción y damnificación del ser. La representación de este mapa mental del cristianismo en su vocación sobrenaturalista es perspicua: como la doctrina y el dogma están anclados en el terreno de lo sobrenatural, el cristianismo se vio forzado a tomar refugio en la admisión de que su verdad no es accesible a la razón. La confianza en Dios debe basarse, no tanto en proporcionar un entendimiento racional de esta doctrina, como por contar con la gracia y la fe necesarias para adoptarla. Esta visión puede entenderse como una invitación a cometer un suicidio intelectual, teniendo en cuenta siempre el argumento de que Dios te resucitará para la salvación. Para apoyar esta idea Rahner cita el siguiente pasaje de Crisóstomo (367):

Puesto que permanece como insondable para aquellos que no tienen el derecho de entenderlo y es revelado no sólo por la sabiduría humana, sino por el Espíritu Santo de tal manera que es posible para nosotros recibir tal Espíritu.

El tono general de la presentación de Rahner es que el cristianismo se ha "sobrepuesto" a los misterios por introducir una dimensión no-naturalista que admite la presencia de ideas irracionales, que requiere una actitud de abandono del intelecto y que necesariamente aparece definida como inaccesible a la razón. La "Cruz" como la base del misterio cristiano constituyó un salto cuantitativo de lo cognoscible a lo incognoscible, de lo natural a lo sobrenatural. En estos términos se expresa Rahner.

La semilla de grano, el árbol germinando, el baño, la vida dada en la unión de los sexos, la luz y la oscuridad, la luna y el sol, todo esto porque precisamente son elementos tan simples y tan humanos proporcionaron, incluso en el ámbito del misterio natural, la expresión más adecuada para lo

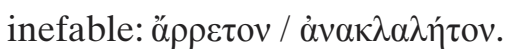


En síntesis, los misterios constituyen esencialmente para Rahner una lectura del universo perceptible por los sentidos y lo que el fatum humano podría estar buscando en él, incluso si el entendimiento científico de estos hechos hubiera sido totalmente erróneo. El cristianismo, según explica a la defensiva Rahner, operó en un plano totalmente distinto y con un contenido divino radicalmente nuevo: el misterio de la Cruz. La Cruz no tiene nada que ver con las creaciones de la naturaleza, o con experiencias de vida simples y humanas. En este sentido, la vida se convierte en algo superfluo para el concepto de salvación. El extendido impulso martirial que, pese a sus raíces judías, causó tanto estrépito e incongruencia a los antiguos demuestra esto. La idea de que uno se dé muerte por adhesión a la fe de un dios hubiera sido impensable para el pensamiento griego helenístico. La proclamada ética cristiana consistió más en la negación de la vida, designada para garantizar que hemos alcanzado el otro mundo. De este modo la ética, a diferencia de una escuela filosófica imperante en este entorno como lo era el estoicismo, puso todo su foco en la mejora y desarrollo de la sociedad, con su compromiso social y facilitó la progresión del mundo. La fe para la salvación fue un elemento preminente, mientras que la salvación fue accesible única y exclusivamente para los que se adhieren a ella. El producto de esta diferenciación provocó históricamente divisiones sociales y una animosidad sin precedentes hacia las prácticas de otros de las que quedan fiel reflejo en las páginas de muchos apologistas cristianos cuya condena de las prácticas paganas se vierte con ensañamiento sobre la dignidad y los derechos de los otros ${ }^{27}$.

Finalmente, Rahner incurre en la falacia habitual propia de los discursos apologéticos de reducir todo el fabuloso y grandioso misterio de la Cruz y de la revelación de Dios a un acontecimiento histórico: la crucifixión de un hombre histórico por Poncio Pilato sobre el monte Gólgota. El "evangelio de Cristo crucificado" es, literalmente, histórico y no tiene a la vez nada de historicidad. No habla de una leyenda remota, sino de un escandaloso y terrible hecho en la historia.

Esta diferencia entre historia y mito es la mayor diferencia existente que defienden los escritores de la era apostólica como Ignacio de Antioquía. De hecho, Rahner y su escuela de seguidores de esta doctrina, afirman sorprendentemente que cualquier investigador de la religión comparada podría haberse aventurado a realizar comparaciones que tratan de derivar la doc-

\footnotetext{
${ }^{27}$ Una muestra de esta postura radical la encontramos en Fírmico Materno, autor del siglo IV d.C. que nos da una información privilegiada sobre los cultos mistéricos practicados en Sicilia.
} 
trina básica del cristianismo directamente de las religiones mistéricas. Pero esta visión no supera ciertas objeciones obvias sobre las relaciones entre mito e historia. De hecho, Pablo nunca habla en términos de historia universal, sino sólo de historia reciente. Al escrito de la carta a los hebreos que sitúa el sacrificio de Cristo en los cielos y nos cuenta que Cristo nunca había descendido hasta la tierra. Al resto de incontables redactores de cartas que no dejan espacio alguno a la figura de un Jesús histórico en sus descripciones de la fe. De hecho, si no se quiere incurrir en una flagrante falacia, el misterio cósmico de la Cruz pertenece no al ámbito terrestre producido por el celo religioso hostil de la autoridad civil romana y judía contra un galileo subversivo, sino al de un acontecimiento brutal, escandaloso y tremendo. Esta es la principal diferencia que detectan entre los misterios y el cristianismo que alegan las tradiciones cristianas posteriores de Ignacio de Antioquía en adelante. Rahner basa en esos postulados su apologética que bien podría resumirse en el hecho de que "la Revelación cristiana no es un mito, sino historia". No obstante, alguien podría refutar esta argumentación señalando que Pablo nunca habla en términos de historia. En primer lugar, no parece que deba existir una diferencia tajante entre ambas realidades. Una cristología tan autorizada como la de Theissen defiende la reconstrucción de un Jesús de la historia y un Jesús del mito. También esto está presente en el escritor de la carta a los Hebreos que localiza el sacrificio de Cristo en los cielos, situando el misterio de salvación en el ámbito mesiánico del Reino. El misterio cósmico de la Cruz no pertenece a una colina de este mundo en las inmediaciones de Jerusalén, sino que se traslada a un paraje verdaderamente cósmico en el mundo espiritual más alto. Esta es la imagen creada por Pablo y por otros representantes de las corrientes místicas que han penetrado directa o indirectamente en el mundo de los cultos mistéricos y, con su base conceptual, han creado un mundo nuevo, de tonos alegóricos espiritualizantes. Los evangelistas han logrado resolver esta controversia en una continua tensión que oscila entre el extremo contradictorio de la recreación mitológica de Cristo y el Jesús histórico y de la historia con el objeto último de resucitar el Hijo de Dios cósmico universal.

\subsubsection{Jonathan Z. Smith: Drudgery Divine: On the Comparison of Early Christianities and the Religions of Late Antiquity (1991)}

De todos los autores analizados, Smith es de los pocos que se plantea establecer un aparato metodológico que le permita con garantías de cientificidad establecer puntos de comparación entre el cristianismo y los mis- 
terios. Para ello, en el apartado inicial de su obra "Comparison: Art or Science?", sienta las bases que le puede llevar a la reinterpretación científica de las relaciones entre movimientos religiosos dispares, adoptando una actitud profesional más neutra, sin llegar a los extremos de la defensa incondicional de los autores cristianos que han tratado de justificar la exclusividad del cristianismo en ese tipo de "exégesis apologética" previa. Comienza el libro con una extensa e interesante explicación ensayística que encuadra contextualmente la obra en su conjunto, consistente en un intercambio epistolar mantenido a lo largo de muchos años entre John Adams y Thomas Jefferson en cuyo desarrollo discutían la "lamentable" (sic) evolución de la primitiva fe cristiana a partir de una original escisión del judaísmo, que fue el estrato religioso representado por Jesús en los sinópticos, hasta la configuración de lo que el autor denomina una corrupción "platonizante" ocasionada por acción del contacto con la gentilidad y, especialmente, con el valor de sus cultos mistéricos. El resultado de todo esto fue la conformación institucional de la Gran Iglesia, la uniformación que dio lugar a la Iglesia Católica de orientación romana y, más tarde, la instauración en época de Carlomagno del Papado que fue responsable de esta corrupción, en su interés declarado por sobreponerse al mundo romano. La Reforma Protestante, según el autor, fue un hito histórico desencadenado por la necesidad de liberar al cristianismo de la degradación de siglos de largo alcance revitalizando el contenido original y el espíritu de las enseñanzas de Jesús. La dicotomía católico-protestante, reflejando la dicotomía entre la verdad y la corrupción, entre el Jesús real y el Cristo platonizado, es una cuestión que Smith demuestra que fue un elemento argumentativo activo en la investigación científica durante años del que todavía uno puede encontrar trazas en el siglo XX. Incluso hoy en algunos círculos exegéticos que evidentemente no compartimos, Pablo sigue siendo visto como un verdadero "corruptor" de la esencia cristiana original, convirtiendo a un individuo histórico, a un predicador, taumatúrgico para algunos, en una monstruosa amalgama platonizante que "enterró el mensaje jesuano en un misticismo sofocante" ${ }^{28}$.

\footnotetext{
${ }^{28}$ Esta es la tendencia más corriente en obras pseudocientíficas, plagadas de prejuicios, que cargan las tintas contra la génesis del cristianismo, tratando de atribuir, el surgimiento del movimiento cristiano en exclusividad a la misión paulina. En el ámbito español un defensor a ultranza de la presunta invención cristiana es Antonio Piñero, quien desde su blog en religión digital y en varias de sus obras, de claro tono divulgativo, ofrece una visión paulinogenética del cristianismo. En cierto modo, Piñero representa la tendencia diametralmente opuesta de los apologistas cristianos. Como es natural, dissimilia similiter y ambas propuestas de sentido, tanto la apologista y exclusivista antimistérico, como la corriente opues-
} 
En las páginas subsiguientes Smith continúa la metodología platonizante, estudiando las bases intelectuales de la Revolución Francesa, entre cuyos representantes, en el ámbito mitológico, descuella la figura de Charles François Dupuis, que, a menudo, ha sido considerado el primer investigador que realizó un enfoque estrictamente como personaje mítico de la figura de Jesús de Nazareth. Dupuis asienta sus teorías en un enfoque mitológico comparado y heliocéntrico. Dupuis también es el primero en adoptar una teoría de modelos cíclicos en los que los movimientos del sol y la primavera, poniendo orden en el caos natural dominante en los estudios de religión comparada, mediante el estudio mítico de los dioses que mueren y renacen (Atis, Adonis, Osiris, etc.) como si se tratase de una cíclica intervención de los dioses en la historia. Dupuis entendió a estos dioses como diferentes manifestaciones del todopoderoso Dios de la luz. Cristo, también fue una divinidad solar "un ejemplo de modelo universal que, habiendo asumido aparentemente un cuerpo mortal, como el héroe de los antiguos poemas, esta será la única ficción de leyenda"29. Smith rechaza la obra de Dupuis como desfasada, Smith reconoce que por primera vez su obra tiene la pretensión de introducir en el campo comparativo un cierto sentido de profundidad metodológica. Especialmente destacable es el hecho de encontrar un camino, un impulso que permita encontrar un camino de salvación certificado en una vida post mortem. Si la esperanza de vida ultramundana se convierte en el horizonte de sentido del ser humano, resulta casi inevitable configurar un universo mítico protagonizado por una divinidad que experimenta la muerte y la supera triunfalmente resucitando a una nueva vida en plenitud.

A la hora de referirse a los misterios Smith utiliza este material comparativo. Su interés fundamental se vuelve a centrar en la figura de Pablo de Tarso. Nadie puede negar que Pablo recurre con frecuencia a la terminología mistérica, aunque su uso de estos conceptos se ha defendido que suponen un tour de forçe radical del uso mistérico tradicional. Tradicional-

ta que pretende ver todo elemento cristiano como dependiente del cristianismo de manera, muchas veces, ahistórica incurren en el mismo tipo de excesos subjetivistas. A pesar de estas posiciones extremas, no deja de ser cierto que en la configuración del cristianismo coincide con la del último proyecto jesuano, que coincide con el horizonte misional de Pablo, como ha quedado claro en el magistral ensayo sobre el Proyecto mesiánico de Pablo de Senén Vidal. Una conexión de la misión paulina coherente con el objetivo del proyecto genuinamente cristiano no contraviene esta otra expectativa.

${ }^{29}$ La pervivencia del "mito cristiano", lejos de toda connotación negativa, supone una de las vetas hermeneúticas más desarrolladas por parte de la moderna exégesis sociológica al combinar elementos de la antigua Religiongeschichtekritik e integrarlos en una dimensión más ecléctica que pretende otorgar una unidad de sentido a toda la experiencia cristiana originaria. 
mente, han existido dos potenciales acercamientos a este tema, que podemos abordar utilizando conceptos de la semántica lingüística.

(a) Polisemia: Pablo tenía en mente matices sémicos en la utilización de estos términos con implicaciones distintas a las que normalmente se tienen de los cultos paganos.

(b) ACOMODACIÓN: Esta actitud implica que Pablo recurrió a la terminología mistérica, moneda de uso corriente en las comunidades gentiles a las que Pablo se dirigió, haciendo de su lenguaje una praxis comprensible para sus destinatarios, presentando la doctrina y prácticas cristianas en términos de palabras e ideas a las que se podrían referir a un auditorio general sin problemas. Esta "acomodación" al lenguaje mítico-cúltico de los misterios, implicaría cierta contemporaneidad y, por tanto, la vigencia de los propios cultos en la primera mitad del siglo I d.C.

Buenos ejemplos del vocabulario mistérico por parte de Pablo los encontramos en 1Cor 15:51,52, donde Pablo revela el misterio de cómo todos vamos a ser cambiados al son de la última trompeta:

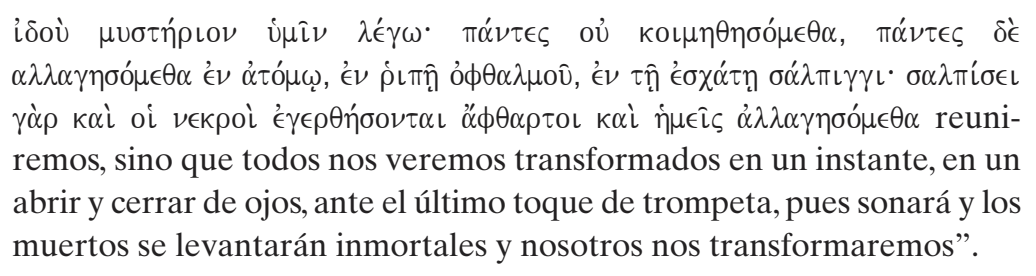

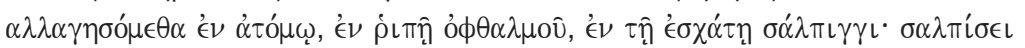

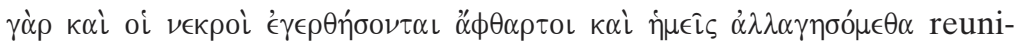
remos, sino que todos nos veremos transformados en un instante, en un abrir y cerrar de ojos, ante el último toque de trompeta, pues sonará y los muertos se levantarán inmortales y nosotros nos transformaremos”.

También resabios mistéricos encontramos en el pasaje de 1 Cor 14,2 en el que se afirma que el don de lenguas, la polilalia, se asimila al hablar de los misterios:

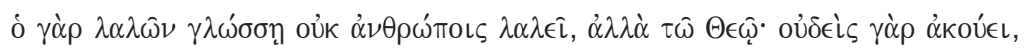
"pues el que habla una lengua, no habla con los hombres, sino $\pi v \in u ́ \mu \alpha \tau \iota$ $\delta \grave{\epsilon} \lambda \alpha \lambda \in \hat{\imath} \mu \nu \sigma \tau \eta \dot{\rho}\llcorner\alpha$ con Dios, pues nadie entiende, sino que en espíritu habla con los misterios".

Además, en términos de proselitismo o de conversión, este tipo de procedimientos se puede entender como retroalimentado, en tanto en cuanto los nuevos conversos abrazaron y adaptaron esta nueva terminología a partir de los términos técnicos del vocabulario religioso que ya conocían previamente por la religiosidad mistérica que habían cultivado durante generaciones. Smith, en este apartado, concretamente se centra en el término re- 
levante de $\mu v \sigma \tau$ ṕpıv. Los estudiosos del asunto mistérico en particular y de Pablo en general señalan que el término $\mu v \sigma \tau$ ńpıov no quiere decir "rito secreto", cuyos arcanos son transmitidos en exclusividad al iniciado, sino que, se le da una perspectiva teocéntrica en virtud de la cual la revelación "secreta" de Dios se revela en exclusividad en el tiempo presente a los iniciados. De esta revelación exclusiva dan buena cuenta varios pasajes paulinos (1 Cor 2:7; Rom 16,25; Ef 3,5, etc.). Muchos de estos pasajes se refieren a $\tau \dot{\alpha}$

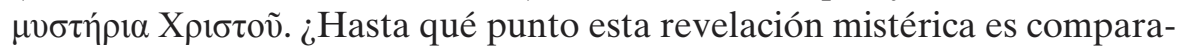
ble a la planteada en la soteriología mistérica? Lamentablemente, esta es una cuestión a la que no se enfrenta directamente Smith. Si estos misterios fueron revelados en una ceremonia ritual privada o mediante una predicación de alcance público no cambia la naturaleza o efecto de los misterios, especialmente cuando Pablo da un especial énfasis a un rito bautismal al que Pablo sustenta como una dramatización ritual básica de la unión del neófito con la divinidad. Si estos misterios se mantuvieron ocultos o fueron mantenidos inaccesibles y ocultos por expreso deseo de Dios o si ellos fueron secretos en el sentido de que no fueron evidentes per se, sino que necesitaron un paulatino recurso al descubrimiento a través de la experiencia ritual, poco o nada modifica el hecho de que ambas prácticas son reveladores de conocimiento y que ambas transforman la imagen del propio iniciado y anticipan su hado escatológico.

Otra táctica apologética encubierta sobre la que Smith llama la atención y que es independiente del significado que se le dé, se refiere al alcance del término $\mu v \sigma \tau$ prov por parte de Pablo y otros escritores de la época "apostólica". Como ha demostrado la crítica exegética, esta voz ha sido derivada, no del milieu helenístico, sino directamente de la interpretación helenizada que supone la traducción de los LXX al griego. Este argumento ya había sido hecho valer por autores de la exégesis más clásica: ${ }^{30}$

Practically every leading conception in this sphere of Paul's religión thought may be said to have its roots definitely laid in that soil [of the Greek Old Testament].

Otros primeros espadas especialistas en la historia del cristianismo, en cierto sentido, también se hicieron eco de esta background judío establecido en el AT como Nock o Metzger. El primero de ellos argumenta que incluso la gentilidad cristiana del siglo I d.C. en cada uno de sus elementos constitutivos puede ser establecida sobre la base del horizonte judío que la conforma y define y que, en consecuencia, ninguna influencia determinante de

\footnotetext{
${ }^{30}$ Kennedy, H.A. (1913): St. Paul and the Mystery Religions, 154-5.
} 
procedencia mistérica puede insuinarse como válida. Este trasfondo cúltico de raigambre judía llega a permear incluso en los títulos cristológicos utilizados y en los ritos bautismales y eucarísticos cuya intelección se basa en conceptos judíos esculpidos en la horma lingüística del uso helenístico de la koiné (LXX).

A pesar de la irremisible pervivencia de puntos de vista como la de Nock por los investigadores posteriores, Smith decide llamar la atención sobre ello. En su exposición, dos notas que se encuentran en el trasfondo del argumento central de Nock de que los LXX pueden ser vistos como "source-book" del campo semántico utilizados por Pablo tal como $\mu v \sigma \tau$ prov y de los problemas que se esconden tras estas asunciones. Una de las principales dificultades interpretativas tiene que ver con la cronología de formación del canon de la Biblia griega de los LXX. La primera traducción del Pentateuco al griego en el Egipto greco-romano probablemente tuvo lugar en el siglo III a.C. Evidentemente, hay una distancia bastante grande respecto a Pablo, pero esto ignora muchos niveles de su compleja historia y desarrollo posterior. Esta visión ignora mucho de los niveles de conformación compleja para esta reconstrucción histórica. El segundo foco argumentativo se basa en el hecho de que la Biblia de los LXX básicamente se esfuerza en dar una detallada explicación en griego del trasfondo exegético rabínico que funda el pensamiento hebreo. Este interés hermenéutico, sin embargo, se ve atenazado por la dura amenaza de tratar de encajonar en odres conceptuales griegos el pensamiento de base judía. A duras penas, el altamente especializado vocabulario griego, dependiente, a su vez, de una esfera de pensamiento político-religioso codificada en términos abstractos de base griega por parte de los traductores podría haber penetrado en forma de calco semántico ${ }^{31}$.

La tarea se complica más si cabe si se tiene en cuenta que la traducción fue elaborada en círculos judíos, seguramente en el entorno alejandrino, dependientes de un tipo de exégesis alegórica de innegable inspiración filoniana. Filón representa un buen ejemplo de cómo el poso judío en la Diáspora reinterpreta totalmente su propia tradición escrita de acuerdo a los principios griegos. De este modo, cualquier influencia que la versión de la Biblia de los LXX puede haber tenido en los escritores cristianos, ya se había establecido en forma helenizada.

\footnotetext{
${ }^{31}$ La prolífica obra de Natalio Fernández Marcos tiene por objeto explicar el clima intelectual que forja la monumental tarea hermenéutica y exegética que supone la traducción de la Biblia de los LXX y el judaísmo helenístico. Alguna de sus obras más relevantes se pueden anotar a modo de ilustración: La Biblia Griega de los $L X X$, CSIC: Madrid.
} 
Descendiendo al dato concreto de los misterios, Smith muestra cómo prejuzga ciertas visiones contenidas en las obras de Nock en lo referente a la terminología. Las relativamente escasas apariciones de la palabra "misterios" en los LXX se encuentran limitadas a seis documentos que reflejan la situación de un judaísmo helenístico evolucionado que sólo indirectamente representan el pensamiento judío tradicional (arcaico) y que, es más, muy probablemente fueron compuestos originalmente en griego кoเví: Daniel, Judit, Tobías, Sirácida, la sabiduría de Salomón y 2 Mac. En cierto modo, por tanto, estos libros de referencia reflejan mucho más el ambiente helenístico que el estrictamente judío. Pero Smith aporta más datos, utilizando como libro de referencia Daniel, libro deuterocanónico no utilizado ni por Kennedy ni por Nock. Daniel sufrió un complejo proceso histórico con constantes relecturas y reinterpretaciones de sucesivas versiones. Además, la fecha de su traducción al griego, probablemente a partir de un original arameo, muy probablemente no se certificó hasta mediados del siglo I d.C., lo que convierte a la LXX de Pablo y a las interpretaciones de Nock en obras prácticamente contemporáneas. Esta hipotética cronología relativa dificulta en gran medida la absorción por parte de Pablo de la rica terminología teológica helenística que absorbe conceptos tradicionalmente hebreos. De hecho, en el siglo I el platonismo influyó en los sectores más evolucionados del judaísmo, dando lugar a la denominada "gnosis judaica". El influjo del platonismo fue decisivo para la irrupción, ya en el siglo II, de la primera teología cristiana postpaulina ${ }^{32}$. El platonismo cristiano tuvo dos versiones. La más moderada estuvo representada por los apologistas, sobre todo por Justino; su intento fue verter al cristianismo en moldes platónicos respetando la letra de la Escritura cristiana. La más extrema es de la de los gnósticos, sobre todo los valentinianos, que, mediante una exégesis alegórica, adecúan el dato neotestamentario a una estructura filosófica netamente platonizante. Ambas teologías constituyen interpretaciones divergentes de la misma tradición religiosa. El platonismo gnóstico no se reduce a una colección de temas paralelos deslavazados, sino que constituye la misma médula de la especulación (no de la fe) de los maestros gnósticos: su fe es la de la Gran Iglesia, su filosofía la de Platón.

\footnotetext{
${ }^{32}$ Una obra de conjunto sobre el platonismo medio es la de Krämer, H. (1964) J. Der Ursprung der Geistmetaphysik, Amsterdam. Para la evolución del platonismo al platonismo medio: Merlan, Ph. (1975): From Platonism to Neoplatonism, The Hague.
} 


\section{El Bautismo en el Horizonte Mistérico Helenístico: Revisión Crítica}

\subsection{Un problema sin resolver}

Dadas las premisas y metodologías esbozadas en el capítulo anterior, si hubiera que seleccionar una obra maestra que representara fielmente la disociación entre el cristianismo y paganismo en lo referente al establecimiento del culto bautismal esta es, sin duda, la de Gunter Wagner, Pauline Baptism and the Pagan Mysteries ${ }^{33}$. Wagner lleva hasta el extremo la crítica apologética antimistérica del cristianismo de los orígenes hasta el punto de convertirse en un fecundísimo best-seller de los foros defensores del cristianismo a ultranza, especialmente en aquellos más amateurs que pretenden eliminar de un plumazo todo mínimo rastro de influencia externa a la de la

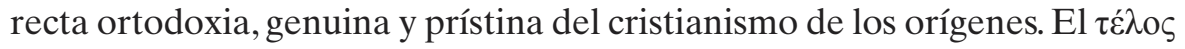
que domina toda la obra pretende solventar un problema que, en opinión de Wagner, ha dominado la visión del cristianismo con consecuencias funestas para su correcta interpretación. Este problema se centra en la presentación del bautismo en tensión que presenta las diferentes visiones de la teología bautismal en el canon del NT. En los sinópticos y en los Hechos el bautismo es un rito de conversión que sigue a una declaración de fe que supone la aceptación del mensaje de Jesús. El bautismo en último término confiere el perdón de los pecados y la recepción del Espíritu Santo. El receptor tomará indudablemente parte en la salvación escatológica. Pero, entonces, si ahora nos limitamos al problema del bautismo en el pasaje clave de Rom 6 nos quedamos sorprendidos por el lenguaje tan absolutamente nuevo que utiliza en los primeros catorce versículos donde habla de la nueva vida liberada del pecado. Muchos autores (e.g. Holtzmann) han manifestado su estupefacción por encontrarse esta concepción tan absolutamente innovadora del rito bautismal dentro del canon del NT. Wagner caracteriza el bautismo según la información de Rom 6 como una acción mística, por medio de la cual el neófito se incorpora a través de la fe al cuerpo místico de Jesucristo. Ciertamente, resulta extraño que aquí Pablo

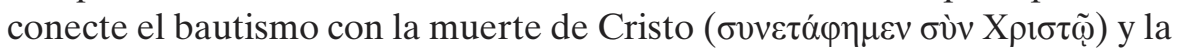
contemple como una muerte con Cristo y una nueva vida con él. Además

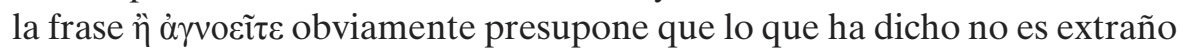
a la comunidad cristiana en Roma. De ello se infiere que el interpretar el

\footnotetext{
${ }^{33}$ Citamos la obra por su traducción inglesa de 1967. Pese al tiempo transcurrido desde su publicación sigue constituyendo una referencia digna de ser tenida en cuenta.
} 
cristianismo en términos de los misterios es una propiedad intrínseca a la comunidad de Roma y, por ello, esta se sitúa en el centro de los intereses de

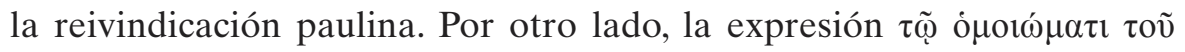
Өavó́ tualización de la muerte y la resurrección de Cristo, y que, como el iniciado en las religiones mistéricas, el creyente comparte el destino de su Señor. Esta impactante y novedosa formulación bautismal se encuentra llena de problemas interpretativos. Así, podría decirse si esto no encontrase apoyo en otros textos paulinos de tono bautismal (cf. Gal 3.27, 1Cor 12,13; 15,29, etc.). Pero muchos más interrogantes le azoran a Wagner ante esta vexata quaestio: ¿puede alcanzarse la interpretación cristiana "premistérica"?, ¿puede adscribirse a Pablo una doctrina de este tenor que no se encuentra tan lejos de una interpretación mágica?, ¿podrá Pablo librarse de la "acusación" de haber filtrado elementos remanentes procedentes del paganismo?, ¿existe una relación real entre los misterios paganos y la novedosa presentación del bautismo que presume Pablo en Rom 6 vel sim.?, ¿la interpretación real del cristianismo ha de entenderse en relación con las religiones mistéricas o simplemente se trata de préstamos terminológicos, pero cuya auténtica explicación debe ser extraída a partir de la propia teología paulina?

Ante este caudal de controvertidas extrañezas metodológicas, Wagner responde con contundente incredulidad, poniendo en solfa las supuestas apariencias de influjo mistérico que supuestamente afloran en las afirmaciones doctrinales del bautismo de Rom 6. El mismo tipo de respuesta se encuentra en el "ala apologética". El resultado de todo ello es que Wagner se termina embarcando en la empresa para desacreditar cualquier tipo de "contaminación" concebible y reinterpretar lo que Wagner y sus lectores hubieran preferido escuchar. Nuestro objeto, será pues, tras examinar los puntos débiles de la defensa de Wagner, una vez presentada su obra, reanalizar sus críticas a la religión y situarlas en un horizonte asimilable a la interpretación teológica más fundamentada y estándar con el fin de contrastarla con el enfoque aportado por los más próximos al modelo de historia de las religiones. En último término, por supuesto, será calibrar el potencial influjo extracristiano en el rito bautismal cristiano originario.

\subsection{Perspectiva general de la obra}

El principal objetivo de Wagner es someter a sumarísimo juicio todo aspecto relativo a los misterios que tenga que ver con el papel de ciertos sa- 
bios dioses que la investigación pasada, especialmente la de la historia de las religiones, presentó como paralelos o influencias más o menos directas con la soteriología cristiana. Todo tipo de supuesto paralelismo previo acaba negándose y desacreditando todo argumento esgrimido para su defensa. Su obra, construida críticamente, sirve como síntesis o recuento de la mayor parte de los trabajos elaborados sobre el tema de los misterios hasta los años sesenta en que Wagner publicó su obra. Mi intención no se centra en pasar revista a todos los puntos críticos de la elaborada argumentación de Wagner, sino criticar algunos de los aspectos más relevantes de su interpretación del bautismo cristiano en su relación con los misterios y observar qué argumentos se han ofrecido desde la teología cristiana para eliminar en perspectiva antropológica todo tipo de contacto entre misterios paganos y sacramentos cristianos, si es que esa línea divisoria se puede trazar sin problemas. Por supuesto, nuestra crítica se basa en el honesto reconocimiento del enorme trabajo filológico de recopilación de materiales que ha utilizado Wagner. Con todo, por otro lado, el peso de ciertas pruebas aportadas por Wagner merece cierto crédito.

$\mathrm{Su}$ análisis parte de la revisión del texto paulino ya introducido antes sobre el bautismo de Rom 6 y su posible relación con los misterios. Junto a este pasaje se añaden otros que Wagner pone en relación con esa visión escatológica del bautismo cristiano:

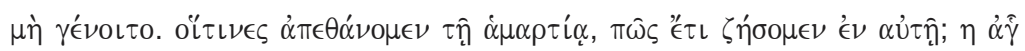

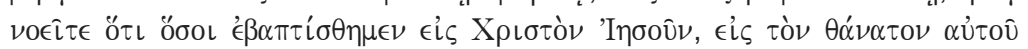

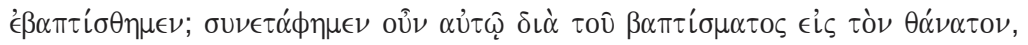

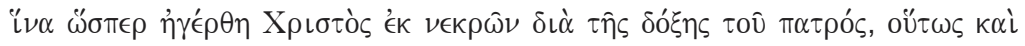

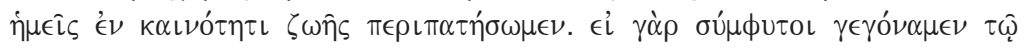

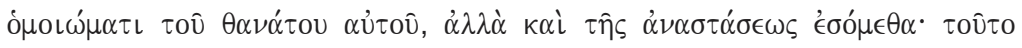

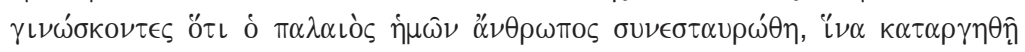

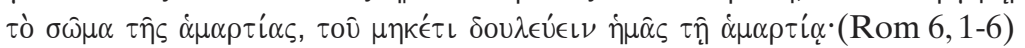
" ".

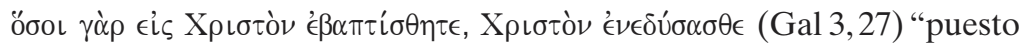
que todos habéis sido bautizados en Cristo, os investíteis de Cristo”.

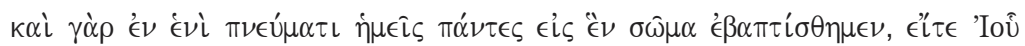

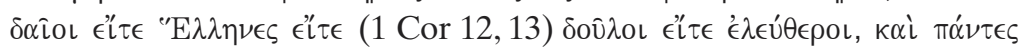

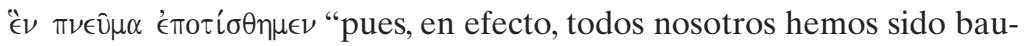
tizados en un solo espíritu, ni judíos, ni griegos, ni esclavos, ni libres y todos se nos ofreció la bebida de un solo espíritu”. 


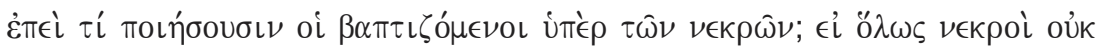

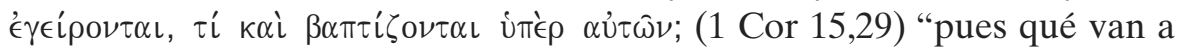
hacer los bautizados en favor de los muertos?, si los muertos no se levantan del todo, por qué también son bautizados en favor de ellos?".

La atención de Wagner se dirige fundamentalmente hacia aquellos exégetas que tradicionalmente han interpretado estos pasajes a la luz de las relaciones mistéricas como Gunkel (1903;1930), Wendland (1912) y Brandon (1955) que, con matices diferenciales obvios, interpretaron Rom 6 en clave

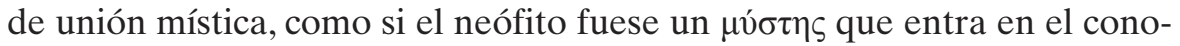
cimiento de una nueva realidad ( $\mu v \sigma \tau \eta ́ p ı v)$. Enumeraremos a continuación los principales argumentos que esgrimen estos autores:

1. El creyente se ha unido místicamente a Cristo.

2. El receptor del misterio experimenta la muerte de Cristo.

3. Se produce el ascenso a una nueva vida impregnada de Cristo (revestida plenamente de Cristo).

4. Se accede a la vida eterna en virtud de este sacramento.

5. La passio Christi le sucede en forma similar al creyente en el sacramento.

Wagner admite que aquellos que se aproximan a Rom 6 desde el AT, desde una perspectiva judaizante, valoran estos asuntos como "incomprensibles y extraños" en la formalización del bautismo de los orígenes y, en consecuencia, resultan difícilmente explicables desde esa perspectiva. En este sentido, Wendland maneja la posibilidad de que Pablo pudo haber tenido contacto con el mitraísmo en Tarso y que, de un modo inconsciente y desinteresado, reconstruyó las ideas mistéricas porque se había encontrado en el ámbito de influencia de estos cultos en Asia Menor. Wendland, quizá de una manera difícilmente probable, establece una estricta comparación entre el bautismo de Pablo con el esquema de iniciación de los ritos mistéricos. El baño ritual de los cultos de Mitra y de Isis, el taurobolium del culto a Cibeles que propicia el renacimiento del creyente y el ascenso en conjunción con la divinidad a una nueva vida son los elementos que supuestamente toma Pablo de las religiones del ambiente mistérico. En su opinión, se puede rastrear una interpretación de tipo "mágico", cuando se administra el bautismo "en nombre de Cristo", pues se suponía que la pronunciación de la fórmula bautismal y del nombre infundían poder y que esta potencia mágica se sustentaba en la infusión del Espíritu Santo que permitía una comunicación entre Dios y el fiel mediante la imposición de manos. Otros 
autores pensaban que el bautismo es una acción de tipo místico-sacramental (Schneider 1954), es decir, "un ritual de reactualización de la muerte y resurrección de Cristo en la persona de cada neófito" y no, por tanto, un tipo de memorial o de desarrollo de una profecía, sino un acto de recreación que propicia la eficacia de los eventos rituales que se transformaban en medios de salvación para el neófito. Sentadas estas premisas, se puede interpretar que el bautismo cristiano fue interpretado en el marco de la historia del pensamiento religioso general y comparado como una práctica de perpetuación ritual de un evento sagrado del pasado (Brandon 1955).

La escueta enumeración de estas posturas nos puede dar una idea de cuáles fueron los argumentos que trató de rebatir el propio Wagner. En esta contraposición, el objetivo de Pablo debe orientarse en dos sentidos:

1. Demostrativo: ofrecer firmes argumentos de que estos elementos mistéricos no estaban incluidos en la teología paulina.

2. Interpretativo: aportar una nueva interpretación de estos textos en perspectiva estrictamente paulina.

Haciéndose eco de una larga tradición interpretativa, Wagner centrará el "exclusivismo" paulino para establecer una diferencia fundamental en lo que se refiere al aspecto ético. La diferencia está bien trazada por una "línea de Apeles". Mientras en los misterios el apartado ético prácticamente no recibe ningún tratamiento, Pablo, en términos de Wagner, centra su teología de la misión en la conformación de una ética estricta. Es innegable, de hecho, que Pablo puso énfasis en la idea de "pecado", mientras que los misterios, por ejemplo, el orfismo, no explotaron suficientemente este aspecto penitencial. Pero esta distinción, como se verá, no resulta tan decisiva como tradicionalmente se ha querido hacer ver. A este respecto es interesante la opinión de Titius (1900): "Pablo desarrolló una concepción del contacto místico del alma con el mundo celeste", lo cual pone el énfasis en la esfera no terrestre que contradice la reconstrucción de su Jesús histórico. La relación entre cielos y tierra, materia y espíritu, no sólo encaja bien en la atmósfera filosófica en la que Pablo se movía, sino que coincide en cierto modo con la característica de los misterios de presentar a los dioses interactuando continuamente con el mista, en una época en la que la exégesis mitográfica neoplatónica había reintepretado en clave filosófica los mitos como eventos que recurren sin tiempo histórico y no como acontecimientos históricos en un lejano y distante pasado remoto.

Wagner llama la atención sobre la perspectiva cristológica defendida por Böhlig (1914). En opinión de Wagner, el fiel cristiano y Cristo confor- 
man una única personalidad indisoluble (es así como habría que interpretar los prefijos $\sigma v v$ - que aparecen a lo largo del texto). Esta indisociabilidad supone, por tanto, que también los acontecimientos fundantes de la fe, la muerte y la resurrección de Cristo, también sean experimentados por el fiel creyente y se comunican al creyente. "Cristo y el creyente forman un solo cuerpo $(\sigma \tilde{\omega} \mu \alpha)$ : "Cristo es la cabeza y los creyentes son los miembros" es una fórmula paulina habitual para describir esta realidad eclesiológica ${ }^{34}$. En esta misma línea se pueden interpretar los testimonios de Gal 3,20 o Gal 4,19. Estas fórmulas paulinas, tan características de su "teología de la Cruz" según defiende Wagner y una corriente bastante consolidada de la exégesis paulina logró promover una postura que se opone a la interpretación de Böhlig para quien estas influencias presentan tonos marcadamente mágicos. La ceremonia bautismal produciría, por su potencia mágica, una trasformación integral del iniciado y la creación de una relación mística total entre dios y el creyente. En opinión de Böhlig en estos textos no se puede vislumbrar ninguna diferencia notable entre la visión paulina y la de los misterios. Con el objetivo de desacreditar esta interpretación automática o mágica de la pertenencia crística, Wagner tendrá como primer objetivo reforzar el carácter sacramental ex opere operato del bautismo cristiano, tal como lo presenta el texto de Rom 6.

\subsection{Ex opere operato}

Este concepto, fundamental en la teología sacramental, da carácter perfomativo a la expresión ritual, creando el efecto salvífico de modo automático e inmediato en el creyente. Esta idea sacramental es la que aparece vigente entre los antiguos y que precisamente fue la crítica fundamental que se le ha imputado en los primeros estudios del Jesús histórico (First Quest). De la misma manera que percibimos las leyes y fuerzas de la naturaleza actuando en el universo, los antiguos percibieron fuerzas espirituales operando entre el mundo natural y el sobrenatural entre la realidad presente terrestre y el pasado primordial o de la más realidad divina. Para Pablo, el rito bautismal constituyó un sacramento en este sentido, como si las fuerzas espirituales invisibles operasen entre el presente y pasado inasibles, entre los cielos y la tierra. El concepto de "sacramento" es en reali-

\footnotetext{
${ }^{34}$ El carácter unitario y de interpretación holística del término $\sigma \tilde{\omega} \mu \alpha$ indicando un "todo" dentro de las partes procede de la literatura clásica. Ya Livio recurre al término corpus revistiéndolo de un sentido institucional en sus Historias al referirse al pueblo de Roma y de las instituciones republicanas como un todo indivisible.
} 
dad una elaboración teológica preciosa de la teología patrística, especialmente dinamizada en el caso de San Agustín, sin embargo, si restringimos nuestra búsqueda sacramental al dato escriturario, se llega a la conclusión de que existe un elemento simbólico y subjetivo, más que performativo en la práctica sacramental antigua construida sobre el principio de analogía. Entre los antiguos era dominante la idea de que los resultados de una acción pueden alcanzarse en el mundo espiritual invisible por la puesta en práctica (ritualización) de hechos análogos en el mundo material visible. Esta interpretación de lo sacramental encaja bien en la idea de que el ámbito de actuación de Cristo es el espiritual al que únicamente los creyentes, por medio de la fe, pueden acceder mediante la perpetración de ritos analógicos ${ }^{35}$. La exégesis contemporánea a estos hechos también desarrolla ideas similares. En concreto, Leipoldt (1908) introduce una afirmación sucinta del principio homológico. Es decir, la idea de que los paralelos contrapuestos entre cielos y tierra que sirven de imagen en la historia de la salvación no son más que una extensión de la idea de cuño platónico, muy extendida en la Antigüedad de que las cosas del cielo se reflejan en la tie-

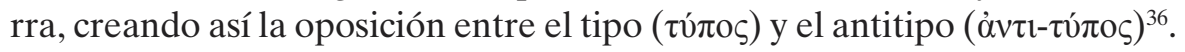
Llevando esto al terreno sacramental, puede afirmarse que aquellos que reviven la fortuna del dios a través de sus sacramentos quedan a salvo. En estos cultos la fortuna del dios va estrictamente ligada a la fortuna de sus creyentes. Es un tipo de mediación que acerca al misterio. Del mismo modo que el creyente nace y renace una y otra vez de la muerte, así también este queda unido a Él por la mediación sacramental ${ }^{37}$.

Sentadas estas premisas, la exégesis de comienzos del siglo XIX alzó su voz contra algunas contradicciones que pueden habérsele imputado a la "teología" bautismal de Pablo en tanto que sacramento. En concreto, el agua en Pablo se identifica con la precondición creyente del reconocimiento sincero de la fe, que es un factor ausente en los misterios. Por otro lado, el

${ }^{35}$ Nota sobre el concepto de sacramento en la tradición patrística. El tratado De Baptismo de Tertuliano puede ser considerado como una de las principales obras que se tienen en cuenta a la hora de iniciar la reflexión teológica sobre el bautismo. Terminológicamente, tanto sacramentum como $\mu v \sigma \tau$ ṕp fueron términos utilizados a partir de finales del siglo II d.C.

${ }^{36}$ Esta es la denominada teoría de la prefiguración o de la tipología en la hermenéutica bíblica, a la luz de la cual todo acontecimiento, personaje, acción divina, etc. acaecida en el AT prefigura necesariamente su posición y su culminación literaria y teológica en el NT. Este tipo de exégesis fue especialmente desarrollada en época patrística y, con gran profusión por la exégesis alegórica alejandrina a partir de Orígenes.

${ }^{37}$ Para un desarrollo sistemático de la teología sacramental es muy recomendable la visión de conjunto ofrecida por Dioniso Borobio (2011) La analogía sacramental, Sígueme: Salamanca. 
énfasis en el aspecto ético y el amor de Dios son elementos que se han privilegiado en el cristianismo, pues estos componentes no se encontraban en los cultos mistéricos en los que, no cabe la muerte voluntaria y vicaria del $\operatorname{Dios}^{38}$. Este conflicto se resolvió viendo en la figura de Pablo moralizando en extremo la interpretación de la doctrina paulina, tal como hizo P. Gadner (1911). Otros exégetas, como Pfleiderer (1905) ven a Pablo como el transformador de conceptos mistéricos más básicos al presentar la muerte de Cristo como el acto moral de autosacrificio del sagrado amor. En consecuencia, parece que es legítimo considerar que Pablo recurrió a las formas y terminologías mistéricas tradicionales para expresar, via eminentiae, los contenidos más profundos y verdaderos de la fe en Cristo. Pero estos elementos claramente influyentes, ni siquiera los más superficiales del ritual, han sido considerados por la exégesis del siglo XX para evitar atribuir cualquier dimensión mistérica que mancille el tipo de cristianismo purificado que está en el trasfondo de los textos paulinos.

El reconocimiento de estos influjos, por otra parte patentes, no ha de obstaculizar la cabal diferenciación entre cristianismo y misterios. Ambos, sostiene Bruckner (1908), por la misma época que el resto de los autores citados, tienen en común poseer una fuente mitológica común, mientras que su influencia recíproca debe ser entendida como debida a su mutuo parentesco. Por otro lado, la historicidad de la persona de Jesús es la verdaderamente central al cristianismo (visión cristocéntrica) y previene al pensamiento cristiano de caer perdido en un capítulo más de la historia general de las religiones. De lo que no queda la menor duda es de que Pablo no ha reconocido hasta el momento la existencia de esta distinción con total claridad. Sólo un análisis exhaustivo de sus cartas tratando de recuperar su opinión sobre el bautismo nos puede ayudar a comprender mejor su interacción con los cultos mistéricos.

\subsection{El rito bautismal en Eleusis ${ }^{39}$}

En su examen del rito bautismal en Eleusis, Wagner desarrolla dos argumentos complejos respecto al tema. El primero de ellos defiende que a

\footnotetext{
${ }^{38}$ Theissen, G. (2007): La religión de los primeros cristianos repasa los mitos asociados a divinidades antiguas que tocan este asunto. E.g. la resurrección de Adonis.

${ }^{39}$ Para una síntesis de los cultos mistéricos, en concreto, los asociados a Adonis, vid. Klauck, H.J. (2005) culto griego de origen fenicio y que muy probablemente tenga puntos de contacto con el culto semítico a Tammuz. También es relevante toda la información que se contiene en el manual de Burkert sobre este culto en cuestión.
} 
pesar de los intentos que se han hecho para certificar que el bautismo de Eleusis significó renacimiento, o para encuadrarlo en un bautismo nupcial, o un misterio de muerte o una imagen de la resurrección, se impone un argumento ex silentio de acuerdo con el cual estas posibles interpretaciones no pueden basarse en los testimonios que nos hayan podido llegar hasta nosotros. Para demostrar la imposibilidad de defender esta postura Wagner señala que únicamente se cuenta con un único testimonio, un relieve votivo eleusino datado en el siglo $\mathrm{V}$ a.C. que representa una escena de bautismo en el que las diosas Deméter y Kore asperjan agua sobre la cabeza del joven iniciado ${ }^{40}$.

Wagner opina que la escena se ha malinterpretado. La forma de asperjar el agua sobre el iniciado obedece a una libre elección del artista de carácter estético. Por el hecho de que esta acción ritual es perpretada por un sacerdote y no por la diosa, se puede indirectamente extraer el valor que se atribuía al bautismo en los misterios. El hecho de que el iniciado reciba el bautismo de parte de la diosa y no directamente del sacerdote no le sorprende a Wagner. puesto que atribuye a este rito un valor mayor del que en principio está dispuesto a concederle en su constante comparación desigual con el cristianismo, pues es consciente de la inexistencia de representaciones de Cristo en persona efectuando el bautismo sobre el convertido. En general, la argumentación de Wagner descansa sobre la crítica a la sobreinterpretación que, en su opinión, ha caracterizado a los autores de la Historia de las Religiones. La interposición constante de filtros como estos constituye un obstáculo insalvable para la correcta interpretación de la realización del cristianismo en su conjunto. Difícilmente puede sostenerse una idea del cristianismo que de entrada cercene tout-court todo contacto externo, por el mero hecho de no cumplir las prerrogativas cultuales cristianas posteriormente fijadas. El segundo argumento todavía es más insidioso e infundado y desvela los intentos apologéticos deliberados del autor y toda intención de contextualizar su descrédito que se sostiene sobre los argumentos contenidos en Tertuliano en su De Baptismo, especialmente en el capítulo 5 de su tratado, lo cual ya supone una elaboración especulativa de la materia doctrinal que se aleja claramente del propósito comparativo original. En el plano estrictamente comparativo, según De Baptismo 5 lo único que podría sacarse en claro es la idea de que en el bautismo eleusino está presente la idea de adopción.

\footnotetext{
Eleusis.

${ }^{40}$ Vid. la imagen el siguiente enlace.: Derechos de imagen del Museo Arqueológico de
} 
Sed enim nationes extraneae ab omni intellectu spiritalium potestatem eadem efficacia idolis suis subministrant. sed viduis aquis sibi mentiuntur. Nam et sacris quibusdam per lavacrum initiantur Isidis alicuius aut Mithrae. ipsos etiam deos suos lavationibus efferunt. Ceterum villas domos templa totasque urbes aspergine circumlatae aquae expiant. Passim certe ludis Apollinaribus et Pelusiis tinguuntur, idque se in regenerationem et impunitatem periuriorum suorum agere praesumunt. "las naciones, que son extrañas a todo conocimiento de los poderes espirituales, adscriben a sus ídolos la inmersión en las aguas con la misma eficacia [...] pues mediante el baño ritual ellos son iniciados en algunos ritos sagrados, por lo demás vertiendo aguas en rededor mediante una aspersión expían villas, casas, templos y todo tipo de ciudades. Por lo demás, ciertamente en todos los eventos celebrativos, en los juegos apolinarios y eleusinos reciben el bautismo, y presumen de que el efecto de hacer esto supone la regeneración y la remisión de los pecados debido a sus perjurios".

En el texto de Tertuliano Pelusiis debe ser leído en lugar de Elusiniis. Al hablar de regeneratio muy probablemente nuestro autor se refiere a una construcción cristiana que se erige sobre los ludi paganos que menciona. En definitiva, tal como introduce estos temas Wagner, da la impresión de que no hay ni referencias primarias, ni secundarias procedentes del mundo antiguo, por lo que todas estas supuestas influencias deben ser interpretadas como engañosas y no centrales. Su afirmación sobre el relato mistérico en la tragedia de Hipólito no deja lugar a dudas, cuando afirma directamente que se deje de lado. Así, en alusión al texto de Tertuliano llega a afirmar que los propios cristianos contemporáneos de Tertuliano no entendieron el verdadero fondo de estas prácticas y son "culpables" (guilty) de leer dentro de ellos los prerrequisitos de sus propias prácticas. Desde luego, la metodología de estos elementos no es extraordinaria. Esta crítica de Wagner es del todo infundada, puesto que, el texto de Tertuliano reconocía el parecido existente entre ambos tipos de cultos.

\subsection{La naturaleza del bautismo paulino}

Lo que la teología bautismal de Lucas expresa como perdón de los pecados y Juan y 1 Pedro expresan como un nuevo nacimiento en Pablo es el fin de una vieja vida y el paso definitivo a una nueva dimensión del ser creatural en el ámbito mesiánico. Contrariamente a las opiniones modernas sobre la fe y el bautismo que interpretan que la fe es la que procura esta 
nueva vida, mientras que el bautismo es una tarea humana subsidiaria. Para Pablo es Dios quien inicia toda acción, haciendo comenzar todo en el bautismo. En otras palabras, la existencia como cristiano no pude tener lugar, sino a partir del bautismo.

Las enseñanzas paulinas sobre el bautismo conectan en el rito la vida del creyente con la muerte y resurrección de Cristo y de él extraen sus consecuencias morales. La asociación del bautismo con la muerte de Cristo lo vincula a una mediación ética y soteriológica para la remisión de los pecados y la asociación con la resurrección lo relaciona con la nueva vida del Espíritu a partir del bautismo. Pablo sitúa el bautismo en el contexto no sólo de la muerte expiatoria de Cristo, sino también de la respuesta de la fe. Ritualmente, el bautismo consistía en una inmersión acuática. En opinión de Pablo, el Espíritu Santo se encuentra activo en el bautismo y se convierte en una presencia perpetua en la vida del bautizado. El bautismo es el motivo de la actividad divina al proporcionar los beneficios de la muerte de Cristo al creyente e introducirlos en la comunidad de salvación.

En definitiva, el bautismo como baño purificatorio, realizado formularmente "en el nombre de Jesús" y en unidad con la acción del Espíritu configuró un medio fundamental de salvación, pero siempre supeditado a la profesión de fe en Jesús muerto en la cruz y resucitado. Estas ideas deben reconstruirse como generalizadas en la Iglesia primitiva, no exclusivas de Pablo, como demuestra el capítulo 10 de Hechos. Los matices introducidos por Pablo se basan en la relación que establece entre el bautismo y la circuncisión de Cristo (su muerte) y su compartición de la sepultura con Cristo. De lo anterior se infiere que el bautismo fue un medio de salvación de importancia fundamental en las comunidades cristianas, pero siempre relacionado con la doctrina paulina de la cruz que supone un acto de adhesión incondicional. Se supone la existencia de cooperación (en la fe), pero la acción decisiva para Pablo procede únicamente de Dios. El bautismo en Cristo fue también el bautismo en el cuerpo de Cristo, la Iglesia. Todo esto tiene consecuencias radicales en la vida del creyente. Deliberadamente, en toda la reflexión paulina he evitado recurrir al carácter "sacramental" del bautismo, si bien se puede reconocer que Pablo y, en general, el NT ofrecen datos contundentes que tienen repercusiones doctrinales y confesionales diversas: en los pasajes que narran la práctica bautismal queda bien claro que Dios actúa a través de símbolos (en este caso, el agua bautismal). Este carácter ex opere operato contrasta con la muy extendida visión compartida por muchas confesiones protestantes que proponen separar el símbolo del efecto simbolizado, como muchos protestantes hacen, y poner el énfa- 
sis, en cambio, en el efecto simbólico propiciado por la bendición, como suele ser interpretado en la doctrina católica de corte romano.

Retomamos aquí la interpretación de Wagner sobre el importante texto bautismal de Rom 6,1-11. En este caso, nos centraremos en tratar de entender qué es lo que Pablo quiere transmitir a la comunidad a la que se está dirigiendo para entender la importancia del bautismo cristiano. Este elemento es fundamental para entender la existencia presente de la comunidad. Hay que tener en cuenta que Pablo nunca ha estado en Roma, de modo que el apóstol de los gentiles no era en absoluto responsable de influir en alguna de su pensamiento religioso ${ }^{41}$. La pregunta que se impone es saber si estas comunidades tuvieron acceso a concepciones bautismales exógenas, especialmente en la esperanza de salvación, tal como aparece testimoniado en las prácticas mistéricas coetáneas. También puede preguntarse si Pablo está construyendo en su doctrina una comprensión de la Iglesia de carácter universal. Otro factor condicionante que no debe pasar desapercibido supone que los destinatarios de la carta en Roma, presumiblemente en los años cincuenta, aproximadamente una década después de la expulsión de todos los judíos de la ciudad, son en su mayoría de extracto gentil. Por otra parte, esto sugiere que su audiencia estaría familiarizada con la doctrina de los cultos mistéricos greco-romanos. Wagner, por tanto, pone toda la carne en el asador para ejecutar una exégesis sobre este pasaje que minimice en lo posible cualquier contacto previo que tuvieran los miembros de la comunidad con otros elementos e influjos externos. La tendencia wagneriana de radicalizar la independencia y exclusividad sacramental del bautismo es clara y aunque su argumentación no persigue claramente la refutación de la idea de que los misterios influyeron en los cristianos a la hora de pensar que compartían la resurrección de Cristo en el bautismo. Wedderburn extrema esta idea un poco más allá y sostiene que Pablo en Rom 6 no tenía la intención de corregir un error de comprensión de la comunidad por situar la resurrección de los cristianos en el futuro. De hecho, Colosenses y Efesios desarrollaron el pensamiento paulino de Rom 6 sin que esto supusiera una revisión radical de la teología bautismal prepaulina $a^{42}$.

${ }^{41}$ Un extraordinario y sencillo comentario sobre este pasaje lo podemos encontrar en Vidal, S. (2011): Las cartas auténticas de Pablo, Mensajero.

${ }^{42}$ Wedderburn, A.J.M. (1987): Baptism and resurrection: studies in Pauline theology against its Graeco-Roman background, Mohr Siebek. 


\subsection{Rom 6, 1-11}

Este es el pasaje fundamental y clave de la concepción bautismal paulina. Las afirmaciones sobre el bautismo en este pasaje deben leerse a la luz de la discusión precedente sobre la fe. La pregunta “¿no sabéis que [...]?" implica la existencia de una fórmula de uso común relacionada con la práctica bautismal en esos pagos. La conexión de la muerte en el bautismo con la muerte de Cristo para remisión de los pecados humanos constituyó parte del mensaje cristiano, pero Pablo profundizó sus consecuencias por su inclinación a distinguir una muerte y elevación con Cristo ${ }^{43}$. Con este vocabulario tan poderoso y enfático Pablo está respondiendo a la acusación (ya sea una objeción real o no) de que su evangelio de gracia conduce a una trasgresión de la ley ( $\dot{\alpha} v o \mu i ́ \alpha)$. Su respuesta se fundamenta en extraer las implicaciones morales asociadas a ser cristiano. Al actuar de este modo, Pablo ofrece una profunda asociación del bautismo con la muerte y resurrección de Cristo. La participación bautismal en esta muerte y resurrección de Cristo tiene como resultado una nueva vida de plenitud y rectitud moral. Una vez más, igual que en Gal $(3,27)$ Pablo recurre a la curiosa for-

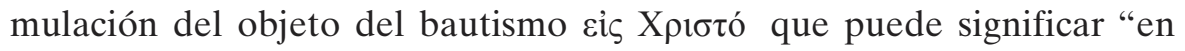
Cristo" o "con referencia a Cristo". Pero en el pasaje de Rom además matiza su afirmación al referirse a la "muerte de Cristo". Da la impresión de que el bautismo "en el nombre de", la fórmula tradicional poco o nada tiene que ver con las fórmulas que se refieren al bautismo "dentro de la muerte" y "dentro de un solo cuerpo" (1Cor 12,13), y, probablemente, estos elementos no tengan la misma fuerza retórica que "en Cristo". El sintagma puede que no tenga la misma fuerza en todos sus usos, pero lo que parece claro, por el conjunto del pasaje, es que la versión "en Cristo" encaja mucho mejor en el contexto que las versiones "en referencia a", pese a que esta no sea la opinión de Beasley-Murray (1999: 139-30) que no extrae la misma conclusión de este pasaje y lo vierte con el giro "con referencia a Cristo" 44 Todos estos comentarios implican que el bautismo es más que algo hecho vagamente con referencia a la muerte de Cristo, sino que implica una identificación total, connatural y participativa en la muerte de Cristo. Morir con Cristo indudablemente significa una muerte al pecado (Rom 6,2). La discusión completa de Rom 6 presupone una conexión de la muerte con el perdón de los pecados. Además, Pablo quiere decir que existe una nueva vida. La sepultura con Cristo fue de tal importancia que, en la misma me-

\footnotetext{
${ }^{43}$ Schnackenburg, H. Baptism in the Thought of St. Paul, pp. 32-37.

${ }^{44}$ Una opinión de similar alcance defiende Schnackenburg, H. op.cit. pp. 25-26.
} 
dida en que Cristo resucitó de entre los muertos, "debemos nosotros caminar en la novedad de la vida" (6,4). Pablo no sostiene explícitamente que en el bautismo uno resucita como Cristo fue resucitado: nuestra resurrección se producirá en el futuro. Estas reservas al hablar de una resurrección bautismal puede que se deban a las conclusiones erróneas que algunos extrajeron de esta misma idea del bautismo "en la muerte de Cristo" (cf. 1 Cor 4,8; 15,13; 2 Tim 2,18). Por este motivo, no se habla de resurrección "con Cristo", sino de ser elevado "como" Cristo lo hizo. Sin embargo, "vivir con él", significa también estar en el presente. Caminar "en la novedad de Cristo" implica una resurrección. En consecuencia, la muerte y resurrección de Cristo operaron conjuntamente en la proclamación del primitivo cristianismo, de modo que el triunfo de la resurrección de Cristo estaba implícito desde el primer momento de la vida cristiana. La identificación del creyente, a través de la fe, con Cristo se explicita por el sorprendente número de compuestos con el preverbio ovv-: "sepultado con", "unido con", "crucificado con", "muerto con", etc. Se describe al creyente con la única experiencia de Cristo en el presente vital. La resurrección futura requiere una resurrección presente en el modo de vivir. La conclusión en el verso 11 refleja la asociación del bautismo con el perdón de los pecados.

En definitiva, no hay participación en la muerte, sepultura y resurrección de Cristo sin bautismo.

El pasaje tiene claras implicaciones para la comprensión activa del bautismo cristiano. La teología bautismal que se vislumbra en este texto puede proponerse sin una semejanza física con Cristo por la intermediación del bautismo, de hecho, muchos creyentes antiguos han disociado la teología de la práctica en la administración del bautismo ${ }^{45}$. Sin embargo, la interpretación textual es más clara. La descripción del bautismo en términos de muerte, sepultura y camino subsiguiente (después de la resurrección) en una nueva vida son ciertamente consistentes con la práctica de la inmersión. De hecho, la analogía con la inmersión en la tierra que supone la sepultura puede haber favorecido la analogía formal. Parece que la rica imaginaría paulina habría que fundamentarla en la praxis ritual del bautismo de la que, sin duda, fue testigo el propio Pablo en sus comunidades. El uso del difícil término "identidad / homogeneidad esencial" del v. 5 (ómotó $\mu \alpha \tau)$ puede entenderse en este mismo sentido. Así, a mi modo de ver acertadamente describe Betz (1996: 115-116) en su traducción "we have

${ }^{45}$ Cf. Kretschmar, G. (1964-1966): "Die Geschichte des Taufgottesdienstes in der alter Kirche”, Leitourgia 5, 31-35, 17, donde ratifica que Pablo seguramente no estaba pensando en la inmersión total, puesto que sólo a partir del siglo IV, en su opinión, se certifica la influencia en las prácticas bautismales de los misterios. 
been united with the likeness of his death", distinguiendo una descripción del bautismo de una verdadera descripción del significado identificando la "similitud" con la inmersión del bautismo, de tal manera que las palabras de Pablo contienen tanto elementos para la descripción como para la identificación del significado de la práctica bautismal conjuntamente.

Pero desde el punto de vista onomasiológico también se pueden extraer inferencias que nos permitan comprobar la evolución del significado del bautismo. La asociación del verbo $\beta \alpha \pi \tau i \zeta \omega$ en sus usos clásicos con una persona que se está ahogando (causa típica de muerte) o una vasija hundiéndose en el terreno de las entidades inanimadas puede también haber sido tomado como el trasfondo lingüístico que ha servido de evocación a $\mathrm{Pablo}^{46}$. Más allá de lo estrictamente textual, la analogía que ha llevado a Pablo a realizar esta formulación quizá pueda rastrearse tras las acciones simbólicas llevadas a cabo por los profetas que, como es sabido, pueden haber influenciado el bautismo de remisión de los pecados practicado por Juan el Bautista y sus seguidores y que constituyen el antecedente directo del bautismo cristiano. Sin embargo, las diferencias vuelven a ser notables. En el caso del bautismo de Juan el bautista, la acción sacramental implica limpieza moral de la materia pecaminosa del creyente, mientras que en Pablo lo que tenemos es la escenificación co-participativa del creyente en el drama de la muerte y resurrección de Cristo que ahora ha experimentado el creyente. Más tarde, los intérpretes de la Iglesia, establecieron una conexión directa entre el bautismo como inmersión total y un enterramiento total que desencadena necesariamente un acto de resurrección, lo cual supone una apertura a nueva vida, una incorporación al Evangelio. La asociación del bautismo con la muerte de Cristo que suponía la remisión y el perdón de los pecados debía de ser probablemente una idea de moneda corriente en las comunidades eclesiales que Pablo fundó, aunque su papel específico consistió en extraer las implicaciones morales del bautismo en la muerte de Cristo.

Un pasaje similar al de la resurrección como el que aparece en 6,4 lo encontramos en la confesión de fe de Rom 10, 9-10. En este caso, el contexto de esta confesión se indica por la lengua del "Señor Jesús" como salvación, una interpretación soberanista, cristológicamente poderosa, que aparece reforzada por la afirmación definitiva de la "no distinción de judío ni gentil" del v. 12, con un tono muy similar al de Gal 3,28 o 1 Cor 12,13. Otros pa-

\footnotetext{
${ }^{46}$ Ferguson, E. (2009): "Words of the bapt-. Root in classical and Hellenistic Greek", en Baptism in the Early Church: History, Theology and Liturgy in the First Five Centuries, Eerdmans: Michigan/Cambridge, pp. 38-59.
} 
sajes indican una confesión de fe de tipo bautismal (e.g. Heb 10, 22-23; 1 Jn 4,15 y Hec 8,37). No es extraño que esto suceda así, cuando sabemos que la designación que se hará posteriormente de los cristianos será difícilmente entendible sin un acto de confesión expreso ${ }^{47}$,

La característica más importante de las enseñanzas relativas al bautismo consiste en conectarlo con la muerte y resurrección de Cristo, de la que se extraen sus consecuencias morales.

\subsection{A modo de conclusión: el eneálogo apologético de Wagner}

Al final de su obra y a modo de epílogo sintético Wagner introduce nueve argumentos contra la "hipótesis de los misterios" (pp. 283 y ss.). Trataré de establecer una síntesis de las opiniones más relevantes utilizadas por Wagner.

1. La dimensión ética asociada a todo tipo de manifestación religiosa no tiene nada que ver con el modelo mistérico. Pese a tal información, Wagner señala que es lógico que Pablo tuviera que basarse en las tradiciones previas sobre las que se fundaba el comportamiento religioso de sus comunidades. Pero no deja de señalar diferencias palmarias. En opinión de Wagner los misterios están marcados por un componente mágico. La magia es un elemento contra el que Pablo se enfrente directamente. Wagner está sobreinterpretando una vez más esto, ya que Pablo de hecho no dirige sus argumentaciones contra estos. En todo caso, la separación del bautismo de la esfera mágica, en los términos en los que esto se producía en la antigüedad tardía es un invento provocado por la moderna argumentación que remotamente tiene que ver con la visión paulina.

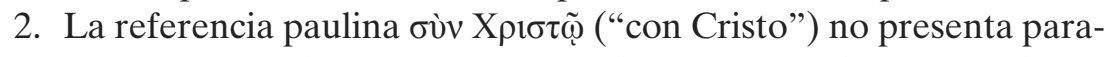
lelos claros en los cultos, es específicamente paulina. Esta afirmación podría verse como si tuviese una derivación general de la idea de "estar en unidad con Dios", a la que se superpondría el propio pensamiento de Pablo en términos de efecto y beneficio para el iniciado. Nadie puede afirmar que Pablo introdujo algo nuevo a su predicación.

\footnotetext{
${ }^{47}$ Alois Stenzel, S.J. (1958): Die Taufe: Eine Genetische Erklärung der Taufliturgie Felizian Rauch : Innsbruck, p. 30 constituye una referencia interesante para el estudio de la función litúrgica original del bautismo como profesión de fe.
} 


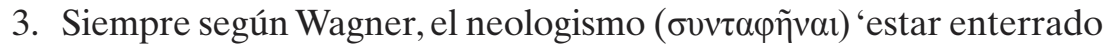
con', que constituye en sí mismo un hápax lleva presente tanta fuerza en nuestro pasaje que, seguramente, debió de admitirse que Pablo se vio obligado a separarse deliberadamente de los cultos mistéricos. El caso es que no queda claro cómo el uso de un verbo

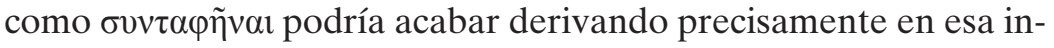
terpretación. Wagner no ofrece paralelos que sostengan esta interpretación, valiéndose, por tanto, de un argumento ex silentio que convierte en una cuestión de fe la argumentación paulina.

4. La muerte por los pecados de Jesús nunca se afirmó de ninguno de los dioses de los ciclos regenerativos de la naturaleza, como los dying and rising gods. Esta afirmación, sin duda, puede ser verdadera, aunque no disponemos de las fuentes escritas que defiendan esta postura radicalmente. De este modo, no tenemos otra opción que ser categóricos. Además, una relación con la idea de pecado, puede igualmente encontrarse en algunas prácticas mistéricas. Como hemos señalado anteriormente, la relación con el pecado, siendo como es una visión particular del pensamiento paulino y de otros autores cristianos primitivos, no elimina, sin embargo, la fundamentación con otros cultos mistéricos.

5. Wagner afirma "the death of Jesus is further distinguised from the fate of all the mistery-deities by the fact that it happened once for all $(\dot{\varepsilon} \varphi \alpha \dot{\pi} \pi \dot{\xi})$, and is incapable of being repeated cultically; here we have an historical event, there a mythical drama". Es evidente que Pablo se está refiriendo a un evento histórico, a pesar de la ausencia de cualquier referencia explícita en todo el corpus paulino (fuera de 1 Tes 2,15-16, ampliamente considerada por los especialistas como una interpolación y 1 Tim 6,13), dentro de las llamadas cartas pastorales, ampliamente vistas por la crítica como el resultado de la labor de un glosador del siglo II d.C. Por otro lado, el "evento Cristo" no cuenta con el rasgo "cíclico", puesto que no presenta parentesco directo con otros mitos agrícolas o cíclicos. En todo caso, en lo que se refiere al taurobolium de Mitra, consistente en el asesinato de un toro, tampoco debía de interpretarse como una representación cíclica. Además, el carácter de una muerte de una vez por todas en Cristo nunca fue presentado en términos históricos por los escritores antiguos. Simplemente podría haberse visto relegado a un ámbito espiritual más alto, en algún punto no especificado del pasado. A este respecto, lo que afirma Pablo es que todo sucedió, en términos platónicos, en la "plenificación de los tiempos". Lo que ha 
sucedido en el tiempo presente, histórico no ha sido otra cosa que la revelación de este evento espiritual con sus consecuencias para la humanidad en términos de salvación, que es ahora accesible universalmente. De este elemento revelacional es de lo que está lleno el corpus paulino, no del evento histórico que supone Cristo.

6. El carácter soteriológico de la muerte y resurrección de Jesús. Respecto a este punto Wagner argumenta que el significado de todos estos eventos presenta una relación directa con el destino del culto a un semidios. Es cierto que en los cultos mistéricos es difícil rastrear una intención por parte de estas divinidades personales para ayudar a los dioses. El significado de esta distinción es relativamente poco importante. Simplemente, puede verse como una mejora de los misterios, determinada por las diferencias culturales, dadas por el carácter propiciatorio que el judaísmo suele atribuir a la muerte de los mártires. En cualquier caso, estoy convencido de que en la mente de los devotos, no estaba presente la idea de que los dioses tenían un consciente interés en proporcionar la salvación. Si esto fue un efecto automático, casi accidental, nos preguntamos ¿por qué existen experiencias como las de fieles como Apuleyo?, ¿por qué el iniciado se sentiría tan unido al dios, si conscientemente sabía que no existía relación con los humanos? En este sentido, Isis, aunque estrictamente no desempeña el rol de divinidad que muere y resucita, es ampliamente representada como un ser divino simpático a la humanidad.

7. Wagner vuelve a sostener categóricamente: "in baptism -in absolute antithesis to the mystery initiations- the primary thing is the historical salvation -even that took place in Jesus, and what the believer experiences is the deliberative".

Estas afirmaciones suponen que el simbolismo externo del proceso exterior del ritual es de naturaleza secundaria. En efecto, el rito cristiano del bautismo es mucho más simple, con muchas menos disposiciones cúlticas que las propias de los ritos mistéricos, si bien esto no prueba nada en un sentido u otro. De nuevo, la argumentación de Wagner se basa en el hecho de que el evento-salvación de Cristo fue histórico. Incluso si esto hubiera sido así, el beneficio derivado respecto al creyente sigue siendo de la misma naturaleza básica que el de los ritos iniciáticos derivados de los cultos mistéricos de la experiencia de Dios. Uno de los principios rectores de la evolución de las ideas consiste en que los viejos conceptos se toman en préstamo 
y se invisten de nuevos significados. El foco de Pablo, repetido de manera casi obsesiva, sobre la idea del pecado como el centro del rito bautismal es un ejemplo de este tipo de adaptación. Uno de los principios fundantes de la evolución de las ideas es que los conceptos más antiguos se reinterpretan con nuevos significados.

8. Volvemos a notar las palabras de Wagner: "thus while -in antithesis to the initiations- does not acquire its significance through the performance of a ritual that works magically, there is nevertheless a corresponding faith-attitude on the part of the candidate, and this attitude of faith is the necessary precondition for receiving it, though of itself it does not make baptism". Glosando estas palabras, podemos afirmar que el argumento de que no hay componente mágico en el bautismo es debatible, como ya se ha indicado en el apartado 1-2. El componente de la fe del bautismo cristiano puede ser única, pero esto no cambia el carácter o la interpretación del propio rito. Simplemente, podría afirmarse que es una condición previa a su operación.

9. Este argumento debe ser desarrollado más cuidadosamente por las implicaciones que presenta. Podemos afirmar que los cristianos en Roma habían sido obligados a entender el bautismo como un sacramento de iniciación, que (como en los cultos de Atis, Adonis y Osiris) garantiza la participación en el destino del culto a la divinidad. La dificultad ahora consiste en reconocer la pervivencia de estas tradiciones referidas a las prácticas bautismales posteriores, durante las cuales florecieron y se desarrollaron como nunca antes. Es difícil trazar un texto o alusión directa en la tradición patrística en la que Rom 6 fue interpretada en referencia o en contraste con ritos o experiencias religiosas "análogas" a las de los mistas de Atis, Adonis u Osiris. Incluso no existen testimonios que funden este tipo de afirmaciones. Sin embargo, Wagner recoge tres textos que indirectamente se refieren al bautismo. Wagner cita tres testimonios, aunque en ninguno de ellos es perceptible la influencia a primera vista. El primer testimonio es la Carta de Bernabé $(10,8)$. En este capítulo, el autor recurre a la Escritura con referencias proféticas al agua / bautismo de la Cruz. Ofrece como paralelos varios pasajes del AT (Isaías, Jeremías, Ezequiel) que hacen referencia al agua, que Bernabé, sin ninguna justificación razonable, interpreta como una referencia velada al futuro bautismo cristiano. Así sucede en el relato de Jeremías $(2,13)$ o Isaías $(33,18)$. El pasaje clave depende de una cita del salmo 1,3: "y será como el árbol, que es plantado en 
los meollos de agua". Para Bernabé esto es una referencia a la cruz y al bautismo. Ahora, aparte de la naturaleza de estas interpretaciones "canónicas" del AT, Wagner debería darse cuenta de que Bernabé a lo largo de toda la carta, primariamente recoge los elementos cristianos presentes y deducibles de la interpretación de las Escrituras con el objeto fundamental de mostrar qué grado de ceguera y estrechez de miras tuvieron los judíos al no percatarse de que Dios estaba aludiendo a la doctrina ritual a través de los profetas. En principio, esta carta relaciona el cristianismo con el judaísmo en lo que se refiere a la "profecía", sin que se perciba ninguna relación directa con los principios paulinos relativos al significado del bautismo. Este silencio en Bernabé, sin duda, es mucho más significativo que cualquier silencio sobre los ritos mistéricos. En opinión del autor de este apócrifo, que Wagner deliberadamente ha obviado, el misticismo paulino es totalmente desconocido para los padres del siglo II, o, si fue conocido en alguna medida, tuvo poco impacto en la conformación de su pensamiento. El siguiente ejemplo de Wagner es el comentario a Ef 18,2. Tras una cita de 1 Cor 1,20, que muestra familiaridad con la carta de Pablo, aunque teológicamente no tiene nada que ver con la idea del bautismo. Ignacio continúa hablando de Jesús como si fuera concebido por María del Espíritu Santo: "nació y fue bautizado el que por su Pasión puede purificar el agua". Ignacio ha obviado este breve pasaje por declarar su devoción a la cruz que, para los cristianos, es "salvación y vida eterna". No hay descripción de las acciones bautismales, tanto en su aspecto intrínsecamente ritual como en sus efectos sobre el bautismo. Es una afirmación de tono místico de cómo Cristo purificó las aguas del bautismo. No hay ninguna referencia en el texto de Ignacio de comparación con los misterios. Indudablemente, podría haber obviado cualquier alusión en una carta pastoral dirigida a una comunidad cristiana. Una vez más, el argumento ex silentio de Wagner es totalmente inapropiado. Ignacio guarda total silencio sobre la interpretación del bautismo de Pablo, hasta el punto de que puede concluirse que Ignacio no tiene ningún interés en el funcionamiento del sacramento. Indirectamente, esto es una prueba añadida de que la fuerza de la doctrina soteriológica de Pablo fue bastante débil, al menos, en la tercera generación de cristianos (siglo II d.C.). Ignacio muestra únicamente conocimiento verdadero de 1 Cor, quizá también de Ef, pero en referencia a otros escritos como Rom no hay seguridad suficiente como para asegurar 
que esto es un hecho. Finalmente, Wagner cita dos textos de Ambrosio y Agustín, ambos autores del siglo IV, citados por Rahner en su famoso artículo de los Papers From the Eranos Yearbook (394), que analizaremos más tarde. A continuación se aportan las citas comentadas:

AMBROSIO: “¿qué es el agua sin la Cruz de Cristo?”, (De mysteriis 4,20). AGUSTÍN: "el agua de la fuente bautismal es consagrada por el signo de la Cruz”, (Contra Iulianum 6,19,62).

Rahner señala que "este misterio es la forma adoptada por la teología paulina, establecida en Romanos, que ve el bautismo y la Cruz de Cristo como un misterio simple". Ambrosio, Agustín e Ignacio comparten la idea de que Cristo a través de la cruz, ha santificado el agua del bautismo. El evento de la crucifixión de Cristo transformó el rito del bautismo para concederle propiedades capaces de conferir ciertos efectos en el receptor del rito. Esto es, solamente en cierto modo, equivalente a la teología paulina del bautismo. Es digno de señalar que no existe mención alguna en estos tres autores sobre el hecho de ser bautizados en la muerte de Cristo o la posibilidad de unirse a él estando libre de pecado y de muerte. Además, la conjunción del bautismo y de Cristo como un misterio simple es una concepción muy general. Tampoco hay mención explícita de que la cruz de Cristo tenga efecto sobre las aguas del bautismo, aunque en el trasfondo de este texto podría estar representado en este pensamiento. Col 2,14 presenta la Cruz como pasaporte, pero en ningún otro autor anterior a Ignacio (Ef $18,2)$, se afirma que la cruz tiene un efecto sobre las aguas del bautismo e incluso aquí se refiere al sufrimiento de Cristo y no a la Cruz propiamente dicha. La última de las concepciones es característica de la Antigüedad tardía y no pertenece, sin duda, al extracto ideológico de los autores del NT. Debe recordarse que en el ensayo de Wagner, ninguno de los ejemplos propuestos (Bernabé, Agustín, Ambrosio e Ignacio) se refiere directamente al concepto de bautismo o, en cualquier caso, sirven para explicar exegéticamente de manera directa Rom 6. Ambrosio describe "para el beneficio de estos bautizados, los ritos y su significado de este Sacramento [...]". Ambrosio nunca cita Rom 6 en el contexto de discutir las obras del bautismo, incluyendo el capítulo en el que Wagner y Rahner han basado su cita. En otro capítulo Ambrosio cita Rom 6,4, pero sólo en el contexto de discusión sobre el bautismo. En otro texto Ambrosio cita Rom 6,4, pero únicamente en el contexto de dirigir el debate sobre si el pecado postbautismal puede ser perdonado. En este documento sobre los "misterios cristianos" no hay 
referencia alguna a Rom 6 como un factor a tener en cuenta en la interpretación y presentación del rito bautismal. No sólo la base de la apología de Wagner se basa en hipótesis falsas, pues en esos autores posteriores no hay referencia alguna al texto en cuestión, sino que incluso Wagner ignora totalmente el contexto de composición del tratado de Ambrosio. No olvide que Ambrosio compone un manual para los iniciados cristianos que se dejan iluminar por los sacramentos. En lo que se refiere a Agustín, he sido incapaz de localizar un texto de Contra Iulianum, pero la cita sugiere que no debe ser incluido dentro del contexto de una discusión general a propósito del significado de Rom 6.

Hasta este momento, hemos pasado revista a los criterios interpretativos que algunos especialistas han atribuido a este pasaje. Hemos incidido en los puntos débiles expuestos por Wagner, sintetizándolo en nueve puntos, especialmente referidos al contenido de Rom 6 sobre el bautismo. En el capítulo siguiente analizaremos cómo la verdadera doctrina bautismal se puede estudiar como un caso de "transferencia cultual" a partir de las prácticas mistéricas.

\section{EL BAUTISMO EN ROM 6 COMO EJEMPLO DE TRANSFERENCIA RITUAL}

Ya hemos visto enfrentados los posicionamientos de los defensores del bautismo como una práctica ritual estrictamente cristiana, directamente derivada de los bautismos de Juan el Bautista que, a su vez, hunde sus raíces en los ritos purificatorios con agua lustral practicados por los judíos en los primeros tiempos, antes de su definitiva formulación y desarrollo sacramentales en la época apostólica. Si algo ha quedado claro es que el bautismo como mediación iniciática cumple una posición ritual que es familiar a otras manifestaciones rituales bien asentadas en las tradiciones religiosas del ambiente original del cristianismo ${ }^{48}$.

Concretamente, como hemos insistido, esas influencias se polarizan en dos sectores significativos. En el ambiente helenístico del paganismo, observamos que son los cultos mistéricos, especialmente ciertos rituales órficos o dionisíacos, ofrecen paralelismos en el proceso iniciático de un miembro que se incorpora a una nueva comunidad religiosa con una identidad interna coherente y plenamente diferenciada. Por el lado cristiano, ya hemos comentado las peculiaridades que hacen de la visión paulina del bau-

\footnotetext{
${ }^{48}$ En este apartado nos hemos basado fundamentalmente en el trabajo de Betz, H.S. "Transfering Ritual: Paul's interpretation of Baptism in Romans 6", en Engberg-Pedersen, T. (2003) Paul in his Hellenic Context,
} 
tismo expuesta en Rom 6, un foco de referencia ineludible para plantear el verdadero trasfondo histórico-religioso en los misterios, que en una visión teológica de tipo sistemático, debe sustentar el armazón de los sacramentos de iniciación.

Sentadas esas premisas, procedemos a analizar Rom 6 a la luz del concepto de transferencia ritual (Kultürbertragung) en el aspecto concreto del acto bautismal. Este concepto tiene el respaldo de haber sido aplicado con éxito a otros movimientos religiosos de la Antigüedad ${ }^{49}$. Continuando con este tipo de análisis, asumiré como punto de partida una comparación de Pablo en el marco de otros "reformadores religiosos" que llevaron a cabo empresas evangelizadoras similares en el mismo marco temporal en el que vivió. En este sentido, se puede establecer, en torno a la figura de Pablo, una evolución coherente interna de la práctica bautismal que se desarrolla desde un origen judío, pasando por las prácticas baptistas de los grupos juánicos y acaba desembocando en la forma final vivida en las comunidades paulinas que recoge Rom 6. Esta transferencia cultural, observable en otros fenómenos sociales en la conformación incipiente de ciertas comunidades religiosas, experimentó las tensiones habituales en su organización, hasta el punto de que la "doctrina" bautismal visibilizada en este transfer cultural se fue progresivamente produciendo a merced de las necesarias tensiones internas observables en la evolución del epistolario paulino. Ya hemos mencionado a este respecto la re-conceptualización constante a la que se ve sometida la propia teología bautismal paulina dentro del corpus de las cartas auténticas y, más agudamente, a su natural evolución en la gestación de la denominada escuela paulina de Colosenses y Efesios fundamentalmente. Estas tensiones relativas a la adecuada formulación del fenómeno del "bautismo" obedecen a las primeras fases de independencia interna de un grupo. La psicología de la religión nos habla bien de ello y la antropología sociocultural ha explicado bien a las claras el funcionamiento interno de estos grupos. Paralelamente, esta visión nos permite densificar la naturaleza nuclear que en las creencias del cristianismo gozaba el bautismo como mediación penetrante en el verdadero Dios y condición soteriológica de primer orden para el creyente ${ }^{50}$. Esta identificación en el siempre difícil terreno de lo religioso es la verdadera justificación de que las rupturistas ideas

\footnotetext{
${ }^{49}$ La formulación original de este tipo de búsqueda del itinerario de tránsito cultual en la historia de las religiones nos remonta a Schmidt, E. (1909) quien acuñó este marbete en su obra Kulturbetrargungen

${ }^{50}$ Räisänen, H. (2010): The Rise of Christian Beliefs. The Thought World of Early Christians, Fortress: Minneapolis y traducido al español en 2011 en Sígueme (Salamanca).
} 
de Rom 6 calaran en la forma mentis de la cristiandad gentil y quizá motivaran su gestación en sus enigmáticos términos.

\subsection{La teología bautismal paulina como iniciación (¿mistérica?)}

Si se examina meticulosamente la intrincada exposición de la doctrina bautismal que Pablo pergeña en 1 Cor, uno se percata de que muy probablemente este abigarramiento se debe a que la doctrina bautismal de Pablo no se fijó definitivamente hasta su maduración definitiva expuesta en Rom 6. Sin embargo, tampoco debe olvidarse que la fórmula de Romanos está intertextualmente basada en la antigua fórmula ya atestiguada en Gal 3, 2628.

Al utilizar esta fórmula, indudablemente, Pablo está dando su aprobación a la vinculación ritual de la iniciación cristiana, tal como la presenta Gálatas. Si no hubiera reconocido su validez, Pablo no hubiera dado al bautismo tanta importancia como la que efectivamente le concede en Rom 6, donde recurre nuevamente a ella. La formulación, sin duda, es muy antigua y los miembros de la comunidad de Galacia tuvieran constancia de ella desde un principio. Sin embargo, su reutilización aquí está especialmente resaltada. Pablo la utiliza como un recordatorio que le sirve para posicionarse en el comienzo de la tradición bautismal paulina ${ }^{51}$. La autoridad de la cita, por otra parte, es lógica, si tenemos en cuenta que Pablo fundó la comunidad de Galacia, por lo que es de suponer que responde a sus concepciones teológicas todo lo contenido de ella. Sin embargo, llama la atención

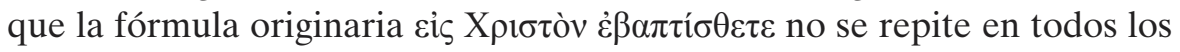
pasajes en los que Pablo trata la cuestión bautismal (cf. 1 Cor 12,13; 10,2, etc.). Será importante ahora tratar de calibrar las motivaciones que han llevado a Pablo a re-conceptualizar su visión bautismal a partir de esta fórmula.

Para empezar a diseccionar qué nos quiere decir Pablo con esta fórmula, no hay más remedio que comprender el vocabulario y las imágenes,

\footnotetext{
${ }^{51} \mathrm{Si}$ aceptamos la noticia de Cipriano (Cartas 69 [75].7.1), formulación que puede documentarse como el primer uso de symbolum en el sentido arcaico de 'compromiso' como respuesta a una profesión de fe. De hecho, en términos puramente de Cipriano, la confesión bautismal de fe tomó la forma de respuesta a un conjunto de preguntas. En el pasaje comentado, concretamente, Cipriano dice de Novaciano, obispo cismático coetáneo al de Cartago, que este hizo la misma pregunta al neófito invocando al Padre, al Hijo y al Espíritu Santo. En sus términos esto se describe como symbolo baptizare 'bautizar mediante el símbolo'. Este uso del sacramentum interrogat estuvo extendido por el Norte de África, de modo que, como confirma una noticia paralela de Cecilio (El Juicio de los ochenta y siete Obispos, 1). Lo más reseñable de todo es que el testimonio de Cipriano es el testimonio más antiguo de la fórmula bautismal como fórmula sacramental y que, por supuesto, es continuadora de la tradición formular trinitaria ya conocida en el canon del NT.
} 
plásticas y forzadas, sobre las que asienta su concepción bautismal. El elemento básico de la fórmula ya ha sido mencionado "seréis bautizados en Cristo". Afortunadamente en Rom 3,27 contamos con una interpretación

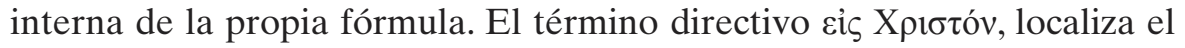
punto final sobre el que se asienta la fórmula. En concreto, en ese otro pasaje la metáfora se reanaliza en términos de revestimiento como Xpıбтòv $\dot{\varepsilon} v \varepsilon \delta \delta ́ \sigma \alpha \sigma \theta \varepsilon$, es decir, revestirse de Cristo como un manto se coloca sobre

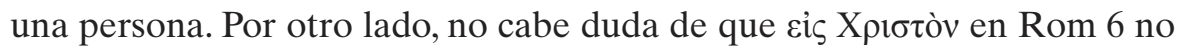
tiene nada que ver con la fórmula de la confesión de fe trinitaria. Más bien, la fórmula adquiere un tono soteriológico que implica la salvación en el evento Cristo. Este elemento no es tan patente en otro tipo de formulaciones. Conferir el rango de "hijos de Dios" a los bautizados resulta en una apertura a una nueva vida, no sólo a ojos de Dios, sino también en el marco social intracomunitario. Todos los nuevos miembros de la Iglesia de Cristo

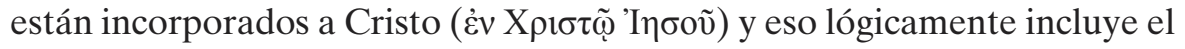
estrato social como bien glosa el versículo inmediatamente posterior en el aspecto étnico "ni judío, ni griego", en el estamento social "ni esclavo, ni libre" ni en la condición antropológica "ni hombre, ni mujer". En su vindicación de la fe, Pablo argumenta que esta salva de todo orden y proclama la superación de toda debilidad por la adhesión definitiva que supone la fe en Cristo resucitado. Esta "igualdad en Cristo" que remonta a los orígenes previos a la división relatada axiomáticamente por el mito de las edades de Hesíodo se sitúa en la estrategia retórica de una controversia y, concretamente, adquiere el clímax expresivo al ser situado en la parte de la proba$t i o^{52}$. El bautismo, en realidad, dice 'dentro de Cristo', por tanto, supone una especie de incorporación definitiva en Cristo, vivencia en su seno, un acceso casi místico a la persona Christi. Tanto su expresión externa como las implicaciones de contenido ritual que van asociadas a ellas parece que deben ser comparadas con los ritos de iniciación, especialmente relevantes, en los cultos mistéricos griegos. Si bien damos por sentado este punto desde un principio, debe advertirse que no es recomendable hablar de "cultos mistéricos" en general, pues cada una de las divinidades reclamaría un tipo de iniciación que otras no poseían, por lo que no está a mi alcance, y no es lugar para hacerlo aquí, valorar hasta qué punto este tipo de iniciaciones comparten patrones homogéneos.

Cuando Pablo reactualiza el lenguaje mistérico en Rom 6 lo hace porque tiene muy presentes las dificultades a las que tuvo que enfrentarse en la comunidad de Corinto. Es consciente que pertenecer a un grupo significa

\footnotetext{
${ }^{52}$ Seguimos la división de la actio retórica de este pasaje propuesta por Betz en su comentario a Gálatas [(2004) Galatians].
} 
establecer lazos de identidad y la comunidad, sin que estos lazos se vieran rotos por la actitud de alguno de sus miembros como queda bien claro en el tono polémico, exhortativo y de insistencia ética que realiza en la carta A de $1 \mathrm{Cor}^{53}$. La tarea de iniciar a unos fieles a un nuevo credo, en definitiva, de fundar una nueva Iglesia, significa que sus miembros deben convertirse en participantes totales de Cristo quien a todos convoca a la unidad con el resucitado, salvador y redentor de toda la Humanidad sin distinción exclusivista alguna. No queda duda de que la iniciación no es una mera conversión ritual. Ser miembro de un cuerpo corporativo como lo es una iglesia local sigue un procedimiento diferente al de la pertenencia a un club social en que esta participación se mide en términos de "cuerpo de Cristo". Este proceso conlleva una vida de duración indeterminada, de forma que el bautismo no supone más que su comienzo. De hecho, esta evolución requiere un proceso en tres etapas que, en cierto modo, pueden encajar con el esquema de van Gennep ${ }^{54}$.

(a) Separación del modo de vida y del ambiente inmediatamente anterior.

(b) Marginación o transición precaria del modo de vida antigua al nuevo.

(c) Agregación o integración en una nueva unidad cultural.

En el caso de Romanos las tres etapas establecidas en el plano teórico por la antropología de la religión se perfilan en paralelo a la teología de la muerte y resurrección en Cristo y de la participación en él que supone una transformación del mundo del pecado a un nuevo éthos cristiano, transición hacia una nueva vida, conformación de vida con Cristo como miembros de una Iglesia y unión escatológica y definitiva con Cristo. Se impone ahora la pregunta: ¿qué razones le llevaron a Pablo a retrasar hasta la composición de esta carta su completa y elaborada doctrina sobre el bautismo?

Quizá Pablo ya había decidido elaborar la teología bautismal tal y como figura en Rom., pero lo había mantenido oculto hasta ese momento. Por otro lado, Pablo puede que se haya visto condicionado por la situación concreta de la comunidad de Roma, que se sabe que practicaba el bautismo, para desarrollar esta visión del bautismo. En relación con la primera propuesta, parece poco probable que Pablo adoptara esta teología bautismal

\footnotetext{
${ }^{53}$ Cf. Vidal, S. (2011): Las cartas auténticas de Pablo, Mensajero, pp.137 y ss.

${ }^{54}$ Van Gennep, A. (1986): Los Ritos de Paso, trad. española del original francés de 1909 Rites de Passage.
} 
antes de la composición de esta carta, para simplemente omitirla. No parece lógico. De hecho, los propios comportamientos intracomunitarios observables en otros focos de la misión paulina podrían haberle dado la oportunidad de desarrollarla. Sin ir más lejos, Gal 3, 26-29 desarrolla una doctrina teológica del bautismo en algunos puntos muy similar a la contenida en Rom. Además, la combinación de theologoúmena no se encuentra en otros lugares, a pesar de que algunas de sus formulaciones ya estén presentes en Gal 3,26-29. Sin embargo, un análisis más pormenorizado nos permite vislumbrar que Rom 6 amplifica el contenido de la formulación bautismal amplificada en Rom 5,1-8,39. De hecho, el concepto de morir y resucitar con Cristo no se encuentra textualmente antes de Rom 6. En este sentido se pronuncia Wedderburn quien defiende que las doctrinas bautismales desarrolladas en Col y Ef no fueron adoptadas por los miembros de la comunidad de Roma y que, en definitiva, Rom 6 no fue compuesto para corregir estas ideas, dejando de lado el modelo de rectitud moral que Pablo trataba de imprimir en las nuevas comunidades que inauguraba. En el bautismo de Rom, Pablo conecta la muerte y resurrección en Cristo con su propia experiencia apostólica, que le sirve como paradigma de imitación a la Iglesia (Gal 2,19-20; 6,14; 17; 2 Cor 4,10-11; Fil, 3,10-11). Por oposición a estas visiones, sin embargo, en Rom Pablo evita situarse a sí mismo y a sus comunidades como paradigma hasta el punto de evitar todo lenguaje que tenga que ver con la imitatio Christi. De hecho, hubiera resultado muy extraño por parte de los romanos imitar a un apóstol al que no habían conocido en persona.

El cambio de actitudes de Pablo pudo parecer ambiguo a los candidatos al bautismo. La crisis corintia le forzó a reconsiderar su posición sobre el bautismo. Puede que sus reflexiones sobre el bautismo afecten también a la comunidad de Roma. En cualquier caso, Rom demuestra que el apóstol finalmente ha presentado una doctrina completa del bautismo.

El siguiente paso es entender cómo desarrolló esta doctrina. La respuesta a esta propuesta se basa en la interpretación del bautismo como un rito de iniciación cristiana. Hemos visto que en la transferencia de cultos la nueva contextualización de rituales a menudo adoptaba la forma de una iniciación. El caso de Pablo es en principio otro ejemplo de este fenómeno. Si esta tesis se prueba como válida, puede también ayudarnos a entender cómo la nueva doctrina, tal como está desarrollada en Rom, está completamente integrada en la argumentación global de la carta. De hecho, basta decir que la doctrina del bautismo es parte de la discusión de la experiencia cristiana de salvación, tal como figura en el desarrollo de los capítulos 5-8. El bautismo marca el punto sobre el que el cristiano individual es "im- 
plantado" en el proceso de salvación, un proceso que se extiende desde Adán hasta la $\pi \alpha \rho o v \sigma i ́ \alpha$.

Después de establecer el significado del propio ritual en Rom 6,3-11, Pablo asume, punto por punto, lo que observa como los beneficia Christi en 6,12-8,39.

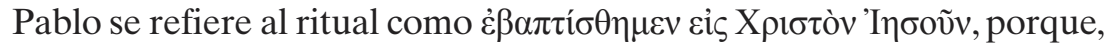
a diferencia de otras referencias al bautismo, en su corpus de cartas (1 Cor 12,$13 ; 1$ Cor 1,13,15) esta expresión queda abierta a varias interpretaciones, sin embargo, el bautismo en su muerte ( La formulación del argumento llama de entrada poderosamente la atención. La argumentación está introducida por una pregunta retórica î ảjvoĩ [...] que puede servir para recordar a los lectores algo que ya sabían. Dados los prerrequisitos teológicos paulinos sobre el bautismo, la conclusión que se alcanza en esta carta es de carácter lógico. No ha de olvidarse que Pablo concibe la experiencia cristiana como una crucifixión con Cristo (

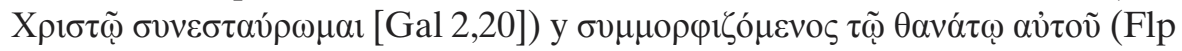
3,10). El bautismo es el punto lógico de comienzo de esta experiencia. Para Pablo, estar crucificado con Cristo es la primera de todas las experiencias de fe, que precede al ritual del bautismo. La experiencia también ha trascendido el bautismo por el hecho de caracterizar toda la vida del creyente, de manera que Pablo puede hablar de compartir la muerte y resurrección sin hacer referencia alguna al bautismo. Sin embargo, es en el momento en el que Pablo decide interpretar el bautismo como iniciación en la experiencia de salvación de Cristo, cuando el ritual bautismal fácilmente podría ser tomado como el punto de partida de esta experiencia iniciática. El bautismo en Cristo implica la performance ritual de lo que sugiere el alcance más amplio del marco mítico-histórico de la tipología de Adán-Cristo (Rom 5,12-21). El contexto de los pasajes que expresan la muerte participada con Cristo desvelan que la muerte y sepultura con Cristo es la precondición necesaria para compartir la esperanza de la resurrección con él.

Mucha mayor dificultad interpretativa conlleva la explicación del pa-

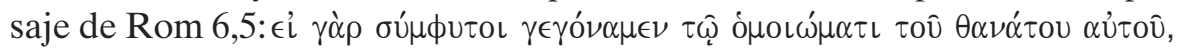

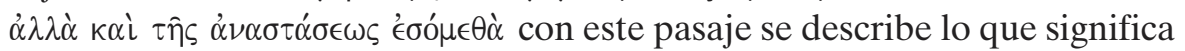
el ritual, en ese caso los exégetas tienen razón en reconocer en esta oración un ejemplo de descripción de un Mysteriendrama, en el que la inmersión en el agua representa muerte y la emersión la resurrección de entre los muertos. Esta interpretación posee además el sello de la tradición y se hizo

\footnotetext{
${ }^{55}$ Interesantísima es la obra de conjunto que analiza las diferentes catequesis mistagógicas y espirituales sobre la iniciación cristiana en la doctrina de los padres: Riley, H.M. (1974): Christian Initiation: A Comparative Study of the Baptismal Liturgy in the Mystagogi-
} 
célebre gracias a las catequesis mistagógicas de Cirilo de Jerusalén ${ }^{55}$. Sus tesis fueron revitalizadas en el siglo XX por algunos eminentes miembros de la Religionsgeschichteschule como Odo Casel y sus seguidores. Pese a que se trata de una interpretación muy interesante y estimulante, los especialistas en NT están todos de acuerdo en el hecho de que no se debe aplicar al propio Pablo. Sin embargo, Pablo debería ser visto como el primer teólogo que mostró el camino de esta interpretación que, posteriormente, en la escuela paulina, sería ampliamente desarrollada en Colosenses y Efesios y en una infinidad de autores. Merece la pena realizar una aproximación al estudio intrínseco de la estructura del texto de Rom 6,1-14 para ver cómo los patrones retóricos magistralmente manejados por Pablo nos ayudan a interpretar la teología bautismal en los términos a los que estamos aludiendo. La secuencia del pasaje parece clara: objeción y respuesta de la tesis (1-2), argumentación en tres estadios paralelos (3-4; 5-7; 8-11), exhortación conclusiva (12-14). Recurre al estilo de la diatriba helenística o diálogo de escuela. Se introduce la objeción de 3,8, pero se formula ahora citando el eslogan de 5,28. No ha de olvidarse que el tono general dominante es el de la instrucción ética paulina en su articulación habitual dinámica conformada en dos dimensiones, tanto en este texto como en otros muchos textos de Pablo y que va de un indicativo "constatativo" sobre la realidad presente y un imperativo abierto a la verdadera y culminante vida futura del "tiempo que resta", del "tiempo escatológico".

En la primera parte se agrupan los versículos 2-5, entre los que el versículo 5 trata de dar sentido a las afirmaciones de los versículos anteriores, recogiendo sintéticamente lo que se explica en los versículos 3-4. A continuación, la afirmación del versículo 5, siendo de carácter explicativo, proporciona los términos requeridos para conectar el ritual bautismal con el significado cristológico y soteriológico que Pablo entiende que debe dotarle. Dicho esto así, supondría que la diferencia entre el ritual y el significado intrínseco por él aludido irían por caminos separados. Por último, los dos términos $\sigma 0 ́ \mu \varphi v \tau o \varsigma$ y ó $\mu$ oí $\omega \mu \alpha$, tomados en conjunto, se esperaría que, por su connivencia, procediesen de contextos en que explican fenómenos

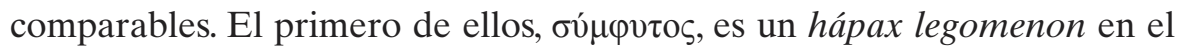
NT, mientras que el segundo aparece atestiguado por todas partes tanto en Pablo como en el Apocalipsis. La elección paulina de estos términos fue, efectivamente, deliberada. Fueron introducidos para iluminar dos problemas esenciales ocasionados por los rituales en general. El primer término,

cal Writings of Cyril of Jerusalem, John Chrysostom, Theodore of Mopsuestia and Ambrose of Milan, The Catholic University of America, Studies in Christian Antiquity, 70 : Washington. 


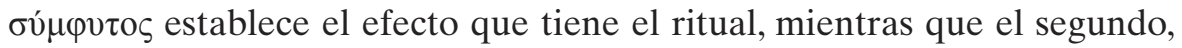

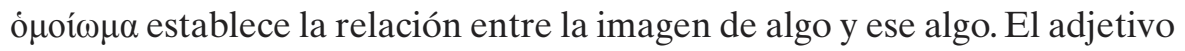
$\sigma 0 ́ \mu \varphi v \tau o \varsigma$ alude a los procesos naturales y confiere la idea de que las entidades naturales crecen juntas. Como metáfora el término fue aplicado también a la interpenetración de las realidades humana y divina. Es sabido que en el pensamiento estoico imperante en este período se defiende que la humanidad primitiva en su origen había estado muy próxima a la divinidad, como defiende en un célebre pasaje Dión Crisóstomo ( r. 12.28.1) que habitualmente se ha puesto en relación con nuestro pasaje de Rom 6. Los parecidos formales ciertamente no pasan inadvertidos, especialmente en los compuestos de бúv-.

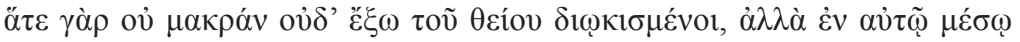

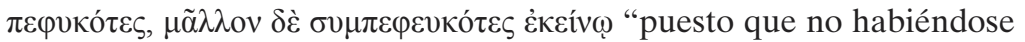
escapado no demasiado lejos del ámbito de la divinidad por su cuenta, sino nacidos en medio de la divinidad misma, y, más bien, connaturalmente surgidos con ella".

Para la interpretación mucha más dificultad entraña el término ómoí $\omega \mu \alpha$, para el que no existe ningún término ni estudio que recoja su verdadero sentido, más allá de los léxicos generales del NT. Incluso en la estructura formal de la carta encontramos algunos problemas de adscripción que nos son ajenos en otros lugares. Así, puede decirse que se barajan dos posibilidades de interpretación:

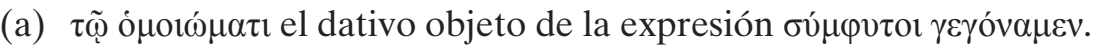

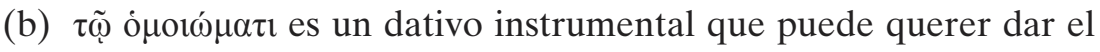
valor a la frase de 'nos hemos unido con Cristo a través de la unidad de su muerte'.

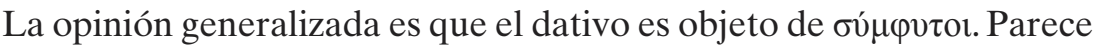
obvio que, en consonancia con su formación morfológica, ó $\mu$ oí $\omega \mu \alpha$ es un abstracto que se refiere al concepto 'bautismo'. La pregunta que naturalmente asalta es el nivel de representación religiosa que debe recibir ahora la palabra "bautismo". ¿Acaso se refiere al ritual del bautismo desde el punto de vista descriptivo, o, más bien, lo hace desde el punto de vista teológico?

Observando en perspectiva más amplia todo el pasaje caracterizado por el dinamismo interno connatural a la teología paulina cabe la duda de 
saber cómo un ritual referido al presente (bautismo) se integra en perspectiva de la muerte de Cristo que es una cuestión del pasado. En apariencia, el uso del término ó $\mu$ oí $\omega \mu \alpha$ en referencia al bautismo hubiera servido como "palabra-bisagra" para aclarar la cuestión.

Haciendo un ejercicio de concordancia lexicográfica y de sus principales quasi-sinónimos ( cuanto ritual $^{56}$. De hecho, otros términos serían inapropiados porque no interviene ninguna imagen de culto (દikஸ́v) y ningún tipo de expresión dramática se realiza $(\mu \mu \eta \dot{\mu} \mu \alpha \tau \alpha)$. El valor, quizá intraducible del término puede ser un tecnicismo propio de la lengua del ritual ( $\tau \grave{\alpha} \lambda \varepsilon \gamma o ́ \mu \varepsilon v$ ). Probablemente se refiriese al elemento ritual similitudo o simulacrum mortis Christi, es decir, a un culto simbólico, a la capacidad transformadora del ritual que presencializa las realidades simbólicas en el espacio ritual. Es sabido que el conocimiento de los símbolos sólo es entendible para aquellos que están iniciados, pero permanece oculto para los aspirantes. De hecho, la fórmula

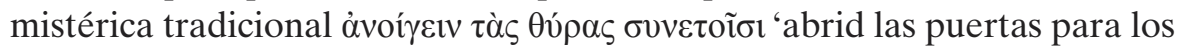
conscientes (sc. de los arcanos)' responde a esta perspectiva del ritual.

Si esta explicación del término ó $\mu$ oí $\omega \mu \alpha$ es correcta querría decir que Pablo está configurando deliberadamente su concepción del bautismo como un tipo de iniciación ritual. Los rituales simbólicos son propios de las iniciaciones. En términos paulinos, la iniciación, ritualizada en el bautismo, supone entrar en unión con Cristo como evento de salvación. El creyente, por el hecho de participar existencialmente en la muerte de Cristo, participó tanto física como espiritualmente en el evento de salvación. El término

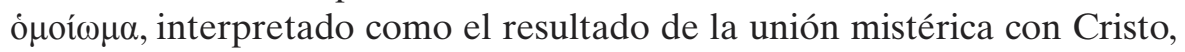
marca una clara diferencia entre la crucifixión de Cristo como un acto histórico del pasado y su representación en el presente. Igualmente, el bautismo se circunscribe en exclusividad al ámbito de la muerte. La resurrección, como deja claro Rom 6,5b (่̇夭ó $\mu \varepsilon \theta \alpha)$, donde vemos la clara contraposición paulina entre un indicativo presente anclado en el espacio de la realidad actual y que se proyecta a un futuro escatológico de cumplimiento definitivo (imperativo). Aunque tampoco sería descabellado valorar, como algunos comentaristas defienden, una extensión del significado de ó $\mu$ oí $\omega \mu \alpha$ aplicada a la Resurrección. El bautismo, entendido de este modo, no implica experiencia (dominio actual de la praxis ritual), sino especialmente conocimiento, cuyo campo semántico de manera explícita domina todo el pasaje en la segunda parte (Rom 6, 6-11). Respecto a esta situación, también Pablo muestra connivencia con las tradiciones de los ritos mistéri-

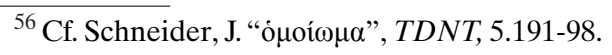


cos. En su caso, también se comunica conocimiento y nuevas experiencias a los iniciados. Además, proporciona un tipo de conocimiento superior que introduce a la participación en la muerte de Dios y resurrección a una nueva vida. Y lo que es más importante, la iniciación marca el comienzo de la transformación de una persona ( $\mu \varepsilon \tau \alpha \mu о \rho \varphi о \tilde{\sigma} \sigma \alpha \iota)$, un concepto soteriológico fundamental para la ética cristiana.

En conclusión, el repaso que hemos realizado a la teología bautismal paulina nos ofrece un cuadro sin contrastes de la institución de rituales iniciáticos en la Antigüedad. Tales modelos de institución entendidos en esta perspectiva pueden, a su vez, ser interpretados tanto en la praxis como en la interpretación de cualquier ritual dado.

En lo que se refiere al bautismo cristiano, es sabido que fue transferido de las prácticas baptistas presentes en la religión tradicional judía. Esta transferencia tuvo lugar por etapas y experimentó muchas recotextualizaciones. El contexto que lo convierte en una práctica cristiana fue, en consonancia con este tipo de transferencias cultuales, el reflejo de diversos movimientos, tensiones y controversias en el marco de la transición de categorías del mundo judío al gentil. No es difícil trazar la historia del bautismo cristiano a partir de Juan el Bautista como terminus post quem. El desarrollo de las subsiguientes etapas lo representamos en el siguiente diagrama evolutivo:

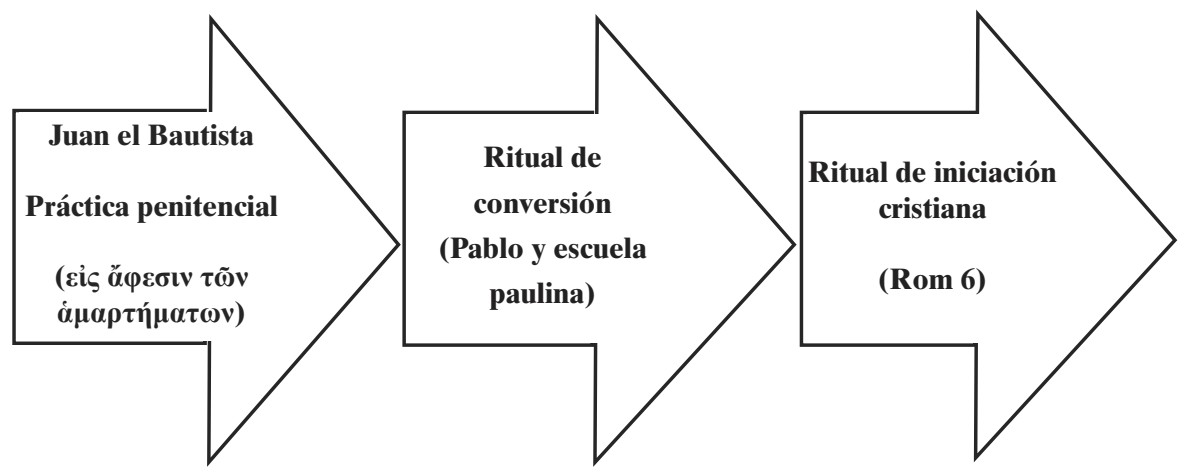

Como hemos indicado más arriba, parece que las crisis con la comunidad de Corinto, llevó a Pablo a la necesidad de dotar al rito bautismal de las comunidades de la gentilidad de una nueva dimensión simbólica. Así surge, como transferencia de los rituales mistéricos del ambiente helenístico, la iniciación cristiana fundada en el texto de Rom 6. En el principio de esta historia, las prácticas bautismales fueron aceptadas sin controversia alguna, 
hasta el punto de que se convirtieron en los estándares de la iniciación cristiana, lo cual explica la ausencia de referencias explícitas al rito en el corpus paulino. Es destacable que si bien las prácticas bautismales nos pasan desapercibidas, sin embargo, el énfasis más grande se pone en el significado teológico del bautismo. Este significado básico o Grundbedeutung se vio modificado por los contextos sociales y religiosos y por las influencias centrípetas que confluían en él. Por tanto, mientras la praxis fue aparentemente transferida sin ningún cambio, la interpretación debía ser recontextualizada. Las cartas de Pablo revelan que aceptó la transferencia del ritual, pero consideró, a través de los datos que le ofreció la crisis de Corinto, que el significado pleno de las relaciones intracomunitarias era inadecuado. Toda esta reactualización de sentido le llevó a Pablo a replantear en su carta a los Romanos a reinterpretar el bautismo en términos de teología. En este nuevo territorio hermenéutico el código de transmisión de las nuevas ideas debía ir anclado a un nuevo constructo de la teología fundado en las ideas mistéricas circundantes en las que lo iniciático cobraba tanto sentido. Tras revisar este texto en su contexto parece innegable la necesidad de recurrir a categorías extracristianas para, al menos, en el rendimiento conceptual de las imágenes, reconfigurar el bautismo dentro de un núcleo simbólico afín a lo sacramental. En este amplio marco de referencia, está claro que aunque hay claras referencias al ritual bautismal, lo fundamental es el aspecto pisteológico del asunto, a saber, la fe en el acontecimiento salvador mesiánico en el que se inician los que siguen su pensamiento. El creyente "murió" en la muerte de Cristo y vive ahora una vida nueva. Es en este trasiego y en este carácter de sustitución inclusiva que gira en torno a la participación de la muerte en Cristo realizada en el bautismo el núcleo conceptual central sobre el que pivota la transferencia ritual tradicional mistérica que hemos ido analizando.

No obstante lo dicho, siempre hay que mantener la novedad cristiana, por más que las transferencias semióticas aportadas por la investigación y replanteadas de continuo establezcan, como hemos visto, elementos de transferencia en analogías con ritos del medio ambiente judío y helenístico. Estos análisis pertenecen a niveles distintos. Al igual que sucede con los banquetes comunitarios para explicar la institución de la Eucaristía, la nota dominante es la coherencia histórica interna que hace plausible que este rito encuentre su función iniciática ya viva en los orígenes del movimiento cristiano. Tanto el rito bautismal, como el de la Cena del Señor eran ritos primordiales y esenciales del cristianismo naciente, cuyos orígenes no se pueden desligar de este y seguramente adquieren su sentido pleno y su justificación histórica de carácter global en la misión de Jesús de Nazaret. No 
cabe duda que tras asumir el bautismo de Juan, el rito bautismal adquirió una nueva dimensión en el cristianismo naciente con referencia directa al acontecimiento de la muerte salvadora del mesías Jesús, como evolución de los ritos juánicos. Ahora, la conversión y el perdón de los pecados que realizaba el rito bautismal de Juan se efectúa en el bautismo cristiano por medio de la comunión con la muerte liberadora del mesías. Es la liberación la que está presente implícita en el ingreso del ámbito salvador mesiánico, inaugurado con la muerte y resurrección del mesías. La antigua tradición bautismal señalaba de diversos modos ese centro clave del rito cristiano que implica una profunda transformación de los bautizados, similar en contenidos a la que encontramos en las celebraciones rituales mistéricas, especialmente en Eleusis. Este elemento transformativo y definitivo que había adquirido el bautismo cristiano desde sus orígenes y que está insinuado en los contenidos bautismales de Juan, cuya esperanza iba a efectuar la gran transformación del pueblo elegido en la época definitiva bajo la antigua fórmula "bautismo con Espíritu Santo". En este sentido, el bautismo cristiano también conservaría un elemento purificador, catártico para el bautizado, canalizado a través de la fuerza divina del Espíritu. Existen paralelos ambientales en este sentido, como, sin ir más lejos, el bautismo purificador de tono escatológico de 1QS 4, 20-22 que expresa la liberación definitiva del futuro. Pero, evidentemente este sería tema de otro tipo de reflexión más amplio.

Estudio Agustiniano Valladolid

Universidad de Valladolid

Instituto Bíblico Oriental de León 